NBER WORKING PAPER SERIES

\title{
APPROPRIABILITY MECHANISMS, INNOVATION AND PRODUCTIVITY: EVIDENCE FROM THE UK
}

\author{
Bronwyn H. Hall \\ Vania Sena \\ Working Paper 20514 \\ http://www.nber.org/papers/w20514 \\ NATIONAL BUREAU OF ECONOMIC RESEARCH \\ 1050 Massachusetts Avenue \\ Cambridge, MA 02138 \\ September 2014
}

This paper was originally written as one of the reports for the project "The choice between formal and informal intellectual property," funded by the UK Intellectual Property Office. We are grateful to Christian Helmers and the late Mark Rogers for their participation in the project and the data construction. We have received useful comments from participants in the CDM Workshop, London, December 2013 Land various seminars. This work contains statistical data from UK ONS which is Crown copyright for Scotland. TheLuse of the ONS statistical data in this work does not imply the endorsement of the ONS in relation Ito the interpretation or analysis of the statistical data. This work uses research datasets which may[not exactly reproduce National Statistics aggregates. The views expressed herein are those of the authorsland do not necessarily reflect the views of the National Bureau of Economic Research.

NBER working papers are circulated for discussion and comment purposes. They have not been peerreviewed or been subject to the review by the NBER Board of Directors that accompanies official NBER publications.

(C) 2014 by Bronwyn H. Hall and Vania Sena. All rights reserved. Short sections of text, not to exceed two paragraphs, may be quoted without explicit permission provided that full credit, including $\bigcirc$ notice, is given to the source. 
Appropriability Mechanisms, Innovation and Productivity: Evidence from the UK Bronwyn H. Hall and Vania Sena

NBER Working Paper No. 20514

September 2014

JEL No. L25,O30,O34

\begin{abstract}
$\underline{\text { ABSTRACT }}$
We use an extended version of the well-established Crepon, Duguet and Mairesse model (1998) to model the relationship between appropriability mechanisms, innovation and firm-level productivity. We enrich this model in several ways. First, we consider different types of innovation spending and study the differences in estimates when innovation spending (rather than R\&D spending) is used to predict innovation in the CDM model. Second, we assume that a firm simultaneously innovates and chooses among different appropriability methods (formal or informal) to protect the innovation. Finally, in the third stage, we estimate the impact of the innovation output conditional on the choice of appropriability mechanisms on firms' productivity. We find that firms that innovate and rate formal methods for the protection of Intellectual Property (IP) highly are more productive than other firms, but that the same does not hold in the case of informal methods for the protection of a firm's IP, except possibly for large firms as opposed to SMEs. We also find that this result is strongest for firms in the services, trade, and utility sectors, and negative in the manufacturing sector.
\end{abstract}

Bronwyn H. Hall

Department of Economics

549 Evans Hall, \#3880

University of California, Berkeley

Berkeley, CA 94720-3880

and NBER

bhhall@nber.org

Vania Sena

University of Essex

Southend Campus Elmer Approach

Southend-on-Sea SS1 1LW

United Kingdom

vsena@essex.ac.uk 


\section{INTRODUCTION}

Innovation is the engine of long-run growth. However innovation does not flourish in isolation but it is the result of the interactions among firms, policy-makers and the institutions that shape the environment where firms innovate. Among the institutions that matter for innovation, the legal system for the protection of the intellectual property has a prominent role and unsurprisingly, its design has been one of the main concerns of the innovation and technology policy across the world. A welfare-enhancing legal system for the protection of the intellectual property has to balance different requirements (Nordhaus, 1969). On the one hand, it has to allow inventors to benefit from their investment by letting them appropriate some of the returns from their inventions. On the other hand, it has to do so in such a way that the social costs associated to the creation of a (possibly short-term) legal monopoly are minimised while not hindering the diffusion of the newly created knowledge across the economic system (Levin et al., 1987; Gallini, 2002; Kultti et al., 2006).

Most of the policy and academic debate around the benefits and the social costs associated to the existence of a legal system for the protection of a firm's intellectual property (IP) has revolved around patents (Boldrin and Levine, 2013; Moser, 2013). This emphasis on patents is mostly due to data availability and economic saliency (given the economic distortions that the award of a patent generates in the economic system). In reality, patents are just one of the instruments that the legal system offers to firms to protect their intellectual property. Mechanisms to appropriate the returns to knowledge assets are typically classified into formal (patents, trademarks, copyrights, and design rights) and informal methods (secrecy, lead time, confidentiality agreements, and complexity).

Survey evidence finds that firms do not consider patents the most effective mechanism to protect their intellectual property. In two seminal papers in this area, Levin et al. (1987) and Cohen et al. (2000) find that lead time and secrecy are considered by U.S. manufacturing firms to be more effective than patents for the protection of their IP. In addition, Cohen et al. (2000) find that patents are mostly used for strategic reasons. More recent data sourced from the UK Community Innovation Survey show that the 
share of firms patenting among those reporting that they have innovated is around 4\% (Hall et al., 2013). Also, Howells et al. (2003) find that formal and informal appropriability mechanisms are used simultaneously by firms and that the type of innovation matters for the choice.

The implication is that any analysis on the relationship among appropriability mechanisms, innovation and firm-level performance needs to take into account two main issues: a) formal and informal appropriability mechanisms are not mutually exclusive and firms can use both at the same time; and b) the choice of the appropriability mechanisms (be it formal or informal) is correlated with the type and quality of innovation. Thus understanding how IP protection can foster innovation and boost firm's performance needs to control somehow for the type of innovations as well as their quality where possible.

This paper builds upon the existing literature on the choice of the appropriability mechanisms and its impact on firm-level innovation and productivity. At the same time, it innovates on the existing literature in two ways. First, we explicitly model the choice that firms make between formal and informal appropriability mechanisms and we test the extent to which this choice is correlated to the type of innovation. Second, we test the possibility that the magnitude of the correlation between firms' performance and the choice of the appropriability mechanism is conditional on the type of innovation.

Modelling the relationship between firm productivity, innovation and the choice of the appropriability mechanism presents a set of challenges. First, it is necessary to define theoretically the channels through which the choice between formal and informal appropriability mechanisms can affect performance. Our key assumption is that the association between performance and appropriability mechanisms is conditional on the type of innovation the IP method is protecting. In other words, firms that are in the process of developing new products or new processes simultaneously decide whether to use formal or formal IP methods to protect the intellectual capital attached to the invention. Once the new products or/and processes are introduced we can observe changes on firms' performance that do not stem directly from the choice of a specific 
appropriability mechanism but rather from the combination of the innovation and how it is protected.

Second, it could be argued that there may be a reverse causality relationship between innovation output and productivity; indeed it well may be that more productive firms may opt for formal IP methods (in particular, patents) as this may for example signal its profitability and long-term viability to investors (e.g., Czarnitzki et al. 2014). To partially address this issue, we assume that the production of innovation and the choice of the IP methods precede temporally the output. If so, we can then model the relationship among appropriability, innovation and productivity in a semi-sequential fashion: in other words, we model the relationship between innovation and the choice among the several methods for the protection of the IP simultaneously assuming that the variables are correlated with each other conditional on observable firm characteristics; then we model the productivity gains a firm may experience conditional on the previous-period innovation output and the choice of the IP method. This does not solve the problem of simultaneity induced by permanent unobservable differences in innovative capacity and output across firms, but it does mitigate any bias arising from transitory effects. Given the fact that the panel structure of our data is very sparse, we cannot do much better than this.

Empirically, we use an extended version of the well-established Crepon, Duguet and Mairesse model (1998) (CDM, henceforth) which connects the production of innovation to the firm performance. Our version of the model is based on the model in Griffith et al. (2006). We enrich this model in several ways. In the CDM model, R\&D is an input to the innovation production process and the knowledge produced by innovation becomes an input to the production function. In the first stage of the model, the decision to invest in R\&D and the R\&D intensity are estimated simultaneously while the innovation production functions and the productivity equations are estimated sequentially in the second and third stages respectively. Our specification differs from the usual CDM model in several respects. First, we do not focus only on R\&D spending but we also consider different types of innovation spending and we study the differences in estimates when innovation spending rather than R\&D spending is used to predict innovation in the CDM model. Second, we assume that a firm simultaneously innovates 
and chooses between the different appropriability methods (either formal or informal IP methods, both methods, or possibly nothing at all). Finally, we estimate the impact on firms' performance of the innovation output conditional on the choice of IP method(s) by estimating a production function augmented by a measure of the lagged innovation output derived from the second stage and conditional on the IP choice.

Our analysis is based on a new firm-level dataset for the UK that combines information from a range of different sources. We merge the three waves of the UK Community Innovation survey (CIS 3, 4 and 5) to the Annual Respondents Database (ARD2) and the Business Strategy Database (BSD), which have information on firms' inputs and outputs. To reduce endogeneity bias in the production function, we use productivity data from the year after the innovation and R\&D data. That is, we merge each wave of the CIS with the subsequent period ARD information (i.e. CIS 4 firms are matched to the 2005 ARD and so on). The resulting dataset contains not only detailed information on firms' selfreported innovation activities from the UK Community Innovation Survey (CIS), but also on measures of firm inputs and outputs that allow to compute estimate the augmented production function at firm-level.

Only 40 per cent of our sample of firms is in manufacturing, with the remainder in services, utilities, trade, and construction. Innovation in these sectors may be quite different from innovation in manufacturing, relying less on $R \& D$ and more on the introduction of new IT-based processes. Our data source provides information on a broader definition of innovation spending of which only about 20 per cent is $R \& D$ spending.

Our key result is that firms who innovate and rate formal IP highly are more productive than other firms, but this does not hold for informal IP by itself, except possibly for larger firms. We also find that this result is strongest for firms in the services, trade, and utility sectors, and negative in the manufacturing sector.

The paper is organised in the following way. Section 2 briefly summarises the relevant empirical literature. Section 3 illustrates the empirical framework we use for our analysis. The structure and the content of the datasets are presented in Section 4 and in 
an appendix, while the results are shown in Sections 5 and 6. Finally some conclusions are presented in Section 7.

\section{APPROPRIABILITY MECHANISMS AND FIRM-LEVEL PERFORMANCE: A SURVEY}

The purpose of this section is to illustrate briefly the literature on the choice between the appropriability mechanisms and their influence on innovation and firm-level performance. In doing so we will identify the main themes and outcomes emerging from this literature and these will then drive our empirical analysis. As mentioned in the Introduction, the innovation literature distinguishes between formal and informal appropriability mechanisms which differ in the nature of the legal rights a firm has in case of violation of its intellectual property. In spite of the emphasis on patents or more generally on formal mechanisms, firms do use both formal and informal mechanisms. This point was first made by Levin et al. (1987) and Cohen et al. (2000). They were both concerned with the extent to which firms in different industries chose legal and nonlegal methods to secure returns from innovation and their findings were broadly consistent. On average, patents are not the most important mechanism to protect a firm's IP while secrecy and lead time are. However, this is not entirely true for product innovations and for industries that are specialized in the production of "discrete" products where patents are still the favourite instrument to secure returns from innovation. These two seminal papers have been followed by a raft of similar studies which have confirmed that the preference for informal appropriability mechanisms is not limited to US firms only. Arundel (2001) focused on the relative effectiveness of patents and secrecy using the CIS I survey for six EU countries and found that firms systematically regard lead-time and secrecy as more important ways to protect their intellectual property than patents. ${ }^{3}$ Laursen and Salter (2005) found that the first mover advantage is the preferred appropriability mechanism for UK firms while Amara et al.

\footnotetext{
3 In this survey, over $50 \%$ of firms ranked lead-time as the most important mechanism to appropriate returns to their innovation and nearly $17 \%$ regarded secrecy as the most important way to protect an innovation. In contrast, only about $10 \%$ regarded patents as the most effective way to secure returns.
} 
(2008) confirmed these findings for Canadian firms from the KIBS sectors but they also found that patents and secrecy tend to be complementary, in line with what has been suggested by other authors (see for instance Howells et al., 2003).

Why do firms use a variety of appropriability mechanisms? Teece (1986) points out that the strength of the legal mechanisms for the protection of a firm's intellectual property, the nature of the technology and the type of knowledge embodied in the technology may influence the nature of the appropriability regime in an industry and in turn, this may drive the choice between the different appropriability mechanisms. So innovating firms may differ in their choice of the appropriability mechanisms and these differences may be due to the characteristics of the knowledge embodied in the invention (for instance, if the knowledge attached to an invention is tacit, then again secrecy may be sufficient to protect an invention), the type of innovation (process innovation can be protected by secrecy as reverse engineering may not be of much help in these cases), industry- and firm-level characteristics (size, innovation strategies etc.). Thanks to the volume of papers which have tried to understand why firms may find some appropriability mechanisms more effective than others, we do have now a good understanding of how each of the above factors influences the firms' choice. For instance, we know that the size of the firm matters. Arundel (2001) finds that large firms are more likely to patent than small firms, likely because of the patent application costs. ${ }^{4}$ Innovation and general business strategies are also found to influence the choice among appropriability mechanisms. For instance, Hurmelinna-Laukkanen and Puumalainen (2007) find that there exists a positive relationship between pursuing short-term value and the use of lead time in a sample of 299 Finnish firms. Hanel (2005) also finds that firms whose strategy focuses on the development of new markets are likely to use formal appropriability mechanisms like trademarks (but not patents) although export strategies are not associated with the use of IPR. Also, involvement in $R \& D$ cooperation has been found to increase the value of patenting because patents help

\footnotetext{
${ }^{4}$ Arundel (2001) also states that this result may be counterintuitive as theoretically small firms may find patents more valuable than large firms as they would help them to enter an industry. Although this is clearly true for a small subset of small firms (those relying on external financing such as venture capital), it may not be true for small firms in general.
} 
to define the property rights among the members of the consortium (Cohen, et al. 2000)..$^{5}$

We do know that the type of industry the firms operates in may influence the choice between different appropriability mechanisms. Some studies have focused on services (rather than manufacturing) and they all suggest that most service firms do not use any IP at all and among those which do, trademarks and copyrights (i.e. formal appropriability mechanisms) are the most used appropriability mechanisms. Among the informal mechanisms, lock-in of customers, suppliers and/or workers is preferred to secrecy (Mairesse and Mohnen, 2003; Hipp and Herstatt, 2006).

The typology of the products also matters. Cohen et al. (2000) divide manufacturing industries into discrete and complex products industries and suggest that in discrete products industries patents are typically used more often than secrecy. In contrast, in complex products industries it is often much easier to invent around technologies and this reduces the incentive to patent and may lead complex-product firms to rely on alternative appropriability mechanisms (like lead time, for instance). Also, product innovations are more likely to be patented than process innovations (Harabi, 1995; Hanel, 2005). This can be explained by the fact that the benefit offered by a patent in the case of process innovations (where reverse engineering cannot be used) may be minimal. The stage of development of an innovation has a bearing on the choice between formal and informal mechanisms For instance, firms may use secrecy when developing a new technology but then apply for a patent when the new product is about to be commercialised (Hussinger, 2006).

Very little is known about the influence that the preference for secrecy (or informal appropriability mechanisms, in general) may have on some indicators of firm's performance. A few studies have focused on financial or innovation performance and have tried to relate them to the firms' preferences for the different appropriability mechanisms. Hussinger (2006) focuses on the percentage of sales and the impact that

\footnotetext{
${ }^{5}$ However, Leiponen and Byma (2009) find that small firms cooperating in innovation with competitors prefer lead time to patents to protect their IP.
} 
the choice between patents and secrecy has on it. Her analysis is based on a data-set of 626 German manufacturing firms and she finds a strong positive correlation between patents and sales of new products, whereas there is no correlation for secrecy. Hanel (2008) focused on profits among Canadian manufacturing firms, modelling the relationship between profits and the choice of the preferred IP mechanism(s) in a twostage model where the first stage estimates the propensity of innovative firms to use IP mechanisms and the second stage estimates the impact of this choice on the profits. The main conclusion is that firms that use formal appropriability mechanisms increase or maintain their profit. Similarly, Hall et al. (2013) find that firms' preference for patents is positively associated to innovative performance measured as turnover due to innovation although there is little relationship between patenting and other measures of performance (like employment growth). These findings seem to suggest that patents are used to protect product innovations which have a direct bearing on profits and sales while secrecy may be rather used either for process innovation or for early-stage inventions that will be commercialised later on.

The studies reviewed here focus mainly on manufacturing where formal IP in the form of patents is traditionally associated to innovation. Services can be different: innovation among service firms may not be technology-related and there might be no benefit from using formal IP protection. ${ }^{6}$ So we could potentially observe innovative service firms which are more productive than their non-innovative counterparts but at the same time, showing a preference for secrecy. A recent study by Masayuki (2014) presents some circumstantial evidence suggesting that higher productivity among services may be correlated with the preference for informal appropriability mechanisms (proxied by their trade secrets holdings) among innovative Japanese service firms.

In summary, this short survey confirms the importance of the informal appropriability mechanisms and their bearing on firm-level productivity and profits. It also identifies some characteristics of the firms, of the technology and of the industries which are

\footnotetext{
${ }^{6}$ Clearly this is an evolving area. To the extent that software and business method patenting are available, some parts of the service sector may indeed benefit from formal IP. In addition, copyright and trademark protection may be very useful in some services.
} 
associated to the choice of the appropriability regime and which we will employ for our empirical analysis.

\section{EMPIRICAL FRAMEWORK}

As mentioned in the Introduction, this section is devoted to the description of the model we use for the empirical analysis. Our model captures the original flavour of the CDM model in that it attempts to model the relationship between the firm's decision to invest in $R \& D$ and the way this is exploited to generate innovation, first and improve their performance, afterwards. Unlike the original CDM model, we model explicitly the choice between formal and informal appropriability mechanisms. We assume that this choice is made simultaneously with innovation success as firms' perception about the quality/type of innovation is correlated the choice of the preferred appropriability mechanism.

One of the well established limitations of the CDM model is that it does not allow one to establish causal relationships but instead describes correlations because the system does not generally permit the identification of true instruments. Our model obviously shares these limitations: indeed, in specifying our empirical model, we do impose some exclusion restrictions based on assumptions which are plausible from an economic standpoint but they are not testable. The implication is that we cannot necessarily predict the consequences of a change in IP behaviour on firms' productivity.

We have tried to mitigate these drawbacks in two ways: first, our empirical model is based on a set of exclusion restrictions which are grounded in economic theory. For instance, we have assumed that the decision to invest in innovation and the amount invested depend on the general IP environment in the sector, but that the firm's own rating of IP is jointly determined with its innovation success or failure. And when specifying the innovation production functions and the equations which govern the preference for the appropriability mechanisms, we assume that the goals of innovation are associated to the production of innovation and not to the choice of IP protection. Second, we have used productivity data in the year following the last year in each innovation survey, so that the innovation expenditure and innovation performance 
precedes the performance measure, although we are aware that this is a weak identification strategy and does not fully solve the endogeneity problem.

Our empirical model is formalised in three stages. In Stage 1, we model the firm's decision to invest in innovation as well as the intensity of the innovation expenditure. In Stage 2, we model in a simultaneous fashion the production of innovation and the choice of the appropriability mechanism. We assume that these are conditional on the innovation expenditure and are affected by other firms' characteristics. We assume there may be unobservables that drive both the firm's propensity to innovate and the choice of the appropriability mechanism. In the third stage, we model the process of exploitation of innovation by estimating an augmented production function where in line with the CDM model, the innovation outputs are introduced among the regressors of the augmented production function; however their correlations with the firm's measure of output are conditional on the choice of the appropriability mechanism. In other words, we allow for the fact that the correlation between output and innovation output varies with the preferred appropriability mechanism. This way, we capture the extent to which the use of a specific appropriability mechanism is associated to a more innovative and productive firm. We will now analyse each stage in more detail.

Stage 1: the first two equations model simultaneously the firm's decision to invest in innovation and the intensity of its innovation expenditure using a sample selection model. Traditionally, the CDM model focus on the decision to invest in R\&D and its intensity but we have decided to expand the model in such a way that different types of innovation expenditures are modelled in this stage with the R\&D expenditure being included as a particular type of innovation expenditure. The decision to invest in innovation is governed by the following equations:

$$
\begin{aligned}
& \text { is } s_{i}=1 \text { if } i s^{*}=w_{i} \alpha+\varepsilon_{i}>0 \\
& \text { is } s_{i}=0 \text { if } i s^{*}=w_{i} \alpha+\varepsilon_{i} \leq 0
\end{aligned} \quad i=1, \ldots, N
$$

Where is ${ }^{*}$ is an unobservable latent variable whose value determines whether the firm invests in innovation, is is an observed indicator which equals zero for firms that do not invest in innovation and one for innovation-investing firms. $w$ is a vector of variables 
explaining the investment decision, $\alpha$ is a vector of parameters to be estimated and $\varepsilon_{i}$ is an error term, assumed to be normally distributed.

Conditional on firms investing in innovation, we observe the amount of resources invested in innovation (modelled here as innovation expenditure intensity - isi i.e. the logarithm of the innovation expenditure per employee):

$$
\begin{array}{ll}
i s i_{i}=z_{i} \beta+e_{i} & \text { if } i s_{i} \neq 0 \\
i s i_{i}=0 & \text { if } i s_{i}=0
\end{array}
$$

where $z_{i}$ is a vector of variables affecting the innovation expenditure intensity, $\beta$ is the vector of coefficients and $e_{i}$ is an error term. Assuming that the two error terms are distributed as a bivariate normal with zero mean, variances $\sigma_{\varepsilon}^{2}=1$ and $\sigma_{e}^{2}$, and a correlation coefficient $\rho$, the system of equations (1) and (2) can be estimated as a generalised Tobit model by Maximum Likelihood estimation.

Stage 2. The second block consists of a set of innovation production functions and the equations which describe the choice between appropriability mechanisms. For our purpose, we distinguish between two types of binary innovation outcomes (product and process innovations) and between formal (patents, design and copyrights) and informal (secrecy, confidentiality agreements, complexity and lead time) appropriability mechanisms. Although ideally we would like to include product and process innovations in the same model, we found that their fitted values after instrumenting were so highly correlated that it was difficult to obtain sensible results when both variables were included in an equation. Therefore, we chose to analyse one type of innovation at a time (product or process) due to lack of identifying power.

We assume that the choice of the appropriability mechanism and the innovation production functions are correlated conditional on their predictor variables and therefore we estimate them using a multivariate model. Formally, the multivariate model is specified as a system of three equations: 


$$
\left(\begin{array}{l}
\operatorname{INN}_{i} \\
I I P_{i} \\
\operatorname{FIP}_{i}
\end{array}\right)=\Phi\left(\begin{array}{l}
\gamma_{1} i s i^{*}+X_{i}^{1} \delta_{1}+d_{s}^{1}+d_{t}^{1} \\
\gamma_{2} i s i *+X_{i}^{2} \delta_{1}+d_{s}^{2}+d_{t}^{2}, \Sigma \\
\gamma_{3} i s i^{*}+X_{i}^{3} \delta_{1}+d_{s}^{3}+d_{t}^{3}
\end{array}\right)
$$

where $\Phi(., \Sigma)$ is the multivariate normal distribution, $i s i^{*}$ is the predicted value of the innovation expenditure intensity (controlling to some extent for the fact that the investment in innovation is endogenous to the production of innovation), the $X$ s are vectors of variables that affect firms' propensity to innovate and their choice between formal and informal appropriability mechanisms, and $d_{s}$ and $d_{t}$ are industry and wave dummies. Each type of innovation output (either new to the firm or to the market) is proxied by a dummy variable (INN) indicating whether the firm has introduced at least one product/process innovation in the last three years. The dependent variables of the two equations which model the choice between the formal and informal IP methods is also measured by dummies variables (FIP for the formal IP methods and IIP for the informal ones): each takes the value of one if the firm rated at least one of the relevant methods as of medium or high importance to the enterprise.

We estimate (3) simultaneously as a trivariate probit system using the GHK algorithm (Cappellari and Jenkins, 2006), assuming that the three disturbances are correlated. As in Griffith et al. (2006), the predicted values from the first stage estimation computed for all firms taking into account the probability that their innovation expenditure is observed are used to proxy innovation effort in the innovation production function. This approach assumes that a firm that reports no innovation expenditure may have still have some informal expenditure related to innovation that is not reported.

Stage 3. The augmented production function is a standard Cobb-Douglas model where the logarithms of labour $(l)$, capital $(k)$, and purchased goods and services $(m)$ are inputs along with the predicted value of the innovation outputs and of the firm's appropriability mechanism. The basic idea is that firms' acquired knowledge has been codified into specific product or process innovations captured in the innovation output variables and that these variables are positively correlated with the firm's performance. 
To control for the potential endogeneity of the innovation output, we use the predicted values from the innovation production functions $\left(I N N^{*}\right)$ rather than the actual values. More importantly, to gauge the extent to which the size of the correlation between output and innovation output varies according to the chosen appropriability mechanism, we interact the innovation output indicator with an indicator taking the value of one if formal/informal appropriation mechanisms are highly rated and zero otherwise. We also include the usual set of industry and survey dummies to control for unobserved characteristics that affect the output level.

Formally, the augmented production function is as follows:

$$
\begin{aligned}
y_{i}= & a+b_{k} k_{i}+b_{l} l_{i}+\pi_{1} I N N_{i}^{*}+\pi_{2} I I P_{i}+\pi_{3} F I P_{i}+\pi_{4} I I P_{i} \bullet I N N_{i}^{*}+\pi_{5} F I P_{i} \bullet I N N_{i}^{*} \\
& +d_{s}+d_{r}+v_{i}
\end{aligned}
$$

\section{DATA AND VARIABLES}

\subsection{Data}

The dataset we have used for our analysis has been constructed by merging several databases compiled by the UK Office for National Statistics (ONS) and made available through the SecureLab at the UK Data Service (UKDS). The databases are the following: the Business Structure Database, containing information about firms' demographic, the Annual Respondents Database (ARD) which has information about inputs/outputs and the UK Community Innovation Survey (waves 3, 4, 5, 6 and 7) which has information about the innovation outputs, the investment in R\&D plus information about the preferred appropriability mechanism. Appendix A has more details about the datasets and the merging procedure.

Our resulting dataset is an unbalanced panel containing detailed information on firms' characteristics, innovative activities over the 13 years period, 1998-2010. However, the main results of the paper refer to the period 1998-2006 and that is because the questions that were asked about IP preferences changed in the CIS 6 and 7: firms were asked only about use of formal IP methods (rather than importance) and no questions on informal methods were included. 
As this paper is concerned with firm characteristics and behaviour that is captured mainly in the CIS, we focus on the sample of firms surveyed by the CIS and we drop all firms from the integrated dataset that have not been sampled in at least one of the CIS waves. This means that we use the BSD and ARD2 only to enrich the dataset available from the CIS. Each CIS refers to several years (CIS 3 to 1998-2000, CIS 4 to 2002-2004, CIS 5 to 2004-2006, CIS 6 to 2006-2008, and CIS 7 to 2008-2010) with 2001 being a missing year. We linked each wave of the CIS with the next period ARD2 (i.e. CIS 4 firms are matched to the 2005 ARD2 and so on) in order to reduce simultaneity problems between our innovation, appropriability and productivity measures. Note that because a new sample of firms is drawn for each CIS (in principle), there is relatively little overlap among the surveys and the average number of observations per firm is about $1.3 .{ }^{7}$ This means that panel data estimation that controls for fixed firm effects is essentially infeasible.

One problem that arises in combining these datasets is the identification of the relevant sampling unit. The ARD2 is apparently sampled at the reporting unit level (which may not coincide with the firm in the case of multi-unit firms), where it is possible that a reporting unit may belong to a larger enterprise, although most of the enterprises consist of a single reporting unit. In principle, the UK CIS is sampled at the enterprise level. Thus for multi-establishment enterprises, there is some ambiguity about whether we have the full complement of data from the ARD2. Fortunately this problem will affect relatively few firms in our sample.

Table A1 in the appendix gives a quick overview of the main characteristics of the basic dataset. The interesting feature of these data is that there is not too much variation across the different CIS waves and this suggests that most of the variation is crosssectional. There are a total of 68,112 observations in the combined CIS 3-7 surveys, of which 48,107 match to the ARD. About half of these either were missing industry, were in the primary industries or in service sectors that were not covered by all the CIS, or

\footnotetext{
${ }^{7}$ In fact, the CIS 5 survey was based on the same stratified sample as the CIS 4 survey, so there is slightly more overlap than implied by drawing a new sample each year.
} 
were non-profits or government firms. ${ }^{8}$ We also lose an additional $\sim 10,000$ observations due to missing values in some of the key variables, or due to sparse coverage in certain 3-digit industries. The resulting sample contains 10,850 observations on 7,255 firms and the sample for CIS3,4,5 contains 7,144 observations on 5,684 firms (or enterprises).

\subsection{Variables}

In the empirical implementation of the structural model outlined in Section 2, we have followed the existing empirical literature on the determinants of the investment in $R \& D$ (and in other types of innovation expenditure) and of the production of innovation in the CDM model.

Stage 1. We assume that the industry-level appropriability environment can influence the amount of innovation expenditure undertaken by firms (although the firm's own innovation success affects its choice of IP directly). This assumption is reasonable as we would expect firms to invest more in R\&D (or any other type of innovation expenditure) if the industry environment is such that they can appropriate most of the returns from their investment (Arrow, 1962). As in Griffith et al. (2006), the variables that capture the industry environment with respect to appropriability are defined as binary variables equal to one if the firm rates any one of the formal (informal) IP methods as of high or medium importance. They are then averaged over 3-digit industry. We use industry rather than firm level information because in the second stage we model the firm's own choice of IP simultaneously with its innovation success.

Additional controls include the firm's propensity to export (here proxied by a dummy variable taking the value of one if the firms has exports) and whether the firm is foreignowned. The first variable captures the notion that exporting firms may be more willing to invest in $\mathrm{R} \& \mathrm{D}$ (or any other innovation spending) as the competition and the learning effect of exporting should enhance its innovative effort (Crespi and Zuniga, 2012). The second variable controls for the possibility that foreign firms may be more innovative

\footnotetext{
${ }^{8}$ The industries deleted were the two-digit sectors (SIC 2007) 1-9 and 80-99.
} 
(and therefore more willing to spend more in R\&D) than national firms potentially because of their superior management practices and human capital (Girma and Gorg, 2007; Kumar and Aggarwal, 2012). Additional controls include size (measured by the $\log$ of the number of employees) and age (measured by the log of the age). The expectation is that larger firms may be more inclined to invest in innovation as it is easier for them to spread the fixed costs of the investment in innovation than for smaller firms (Cohen and Levin, 1989; Cohen and Klepper, 1996). Equally, the empirical literature suggests that older firms tend to invest more in $R \& D$ than younger ones because of the need for specialist skills that younger firms may lack (see for instance Zahra et al., 2005), although it is possible that new entrants in technology sectors actually invest at a higher rate in the hope of future sales. Thus the age effect can go either way.

We also control whether the firm has a cooperative arrangement with another organisation for innovation by introducing a dummy variable taking the value of one for those firms which have a cooperative arrangement. Several authors suggest that collaboration stimulates further innovation investment by allowing firms to share costs and internalising knowledge spillovers (see Kamien et al., 1992). We also include a set of categorical variables indicating the intensity of use of different information sources in innovation-related activities (Crespi and Zuniga, 2012; Griffith et al., 2006); these take the value of 1 if information from internal sources/ customers/ suppliers/ competitors/ universities was of high or medium importance. As in Griffith et al. (2006), we introduce demand-pull factors (namely related to the need to meet regulations and industry standards) in our equations which are proxied by the share of firms in the 3-digit industry for which meeting regulations or standards were of high, medium, or low importance for innovation (as opposed to no importance). ${ }^{9}$

We control for industry-level perception of barriers to innovation due to either financial constraints or uncertain demand for the new products. Several papers suggest that financial factors are an important impediment to R\&D spending (Hall, 2002; Hall and

\footnotetext{
${ }^{9}$ Note that because we also include 2-digit industry dummies in the regressions, the demand pull effects are measured relative to the average for the relevant industry.
} 
Lerner, 2010). ${ }^{10}$ Equally, industries characterised by uncertainty in the new products' markets are characterised by low levels of R\&D spending. ${ }^{11}$ The average perception of financial constraints for innovation and constraints due to market risk (uncertain demand) in the 3-digit industry are each measured as the average of the qualitative indicator 0,1,2,3. Finally, we have included 25 dummy variables for the 2-digit industry to which the firm belongs, and 2 dummy variables for the CIS waves. The excluded industry is automobile manufacturing and the excluded wave is CIS3.

Stage 2. The key independent variable in Stage 2 (and appearing in all the equations of Stage 2) is the predicted value of the log of the innovation expenditure intensity (derived from the first stage estimates). As mentioned in Section 2, this way the model takes into account the fact that the innovation expenditure is endogenous to the production of innovation and to firm's preferences in relation to the appropriability mechanisms.

The innovation and appropriability equations share some independent variables with the equations from Stage 1: size, age, the dummy for cooperation and the dummies for the sources of information. The rationale for including them among the regressors of the innovation equations is quite similar to the one offered in the previous stage. Older and larger firms are more likely to innovate successfully as they have the necessary experience and capability to transform their innovation investment in innovation output. The same argument applies to firms which are in a cooperation agreement for innovation with other organisations.

As for the appropriability equations, Arundel (2001) finds that large firms are more likely to patent than small firms because of the costs associated to the enforcement of patents. Involvement in inter-firm cooperation has also been found to influence the choice of the IP method. Firms that engage in cooperative arrangements may be

\footnotetext{
${ }^{10}$ Also, Canepa and Stoneman (2008) report that firms from high tech industries are more likely to report a project being abandoned or delayed thanks to financial constraints.

${ }^{11}$ See for instance Tiwari et al. (2007) for a study of how financial constraints interact with market uncertainties (among the others) and influence R\&D spending.
} 
interested in using formal IP methods as patents would help them when bargaining with the other partners of the research consortium (Cohen et al., 2000). Finally, the use of different types of information sources can be associated to the preference for specific IP methods. For instance, firms which source information from universities may be more likely to patent while those which source information from competitors or suppliers may prefer to use secrecy or lead time to protect their IP.

Consistently with the empirical literature in this area, we also control for the perceived financial constraints (taking the value of 1 if the firm is constrained and 0 otherwise) and the perceived demand for innovation (taking the value of 1 if the firm considers the demand for innovation too uncertain) in both the innovation and the appropriability equations. Financially constrained firms are less likely to produce innovation while at the same time they may prefer informal IP methods (see Hall et al., 2013 and Scellato, 2007). Also, firms which face an uncertain demand for innovation may decide to patent anyway because of the real option that patents generate (Bloom and Van Reenen, 2002).

We also include two indicators of demand-pull factors for innovation: whether the firm rated meeting regulations or standards of medium or high importance for innovation (as opposed to no or low importance) and whether environmental concerns were of medium or high importance for innovation (as opposed to no or low importance). We also control for the industrial sectors as well as the CIS wave.

To identify the equations, we assume that the direction of innovation (i.e. the reasons to innovate) is associated to the production of innovation but not to the preference for formal and/or informal appropriability methods. Therefore, in the product innovation equation we introduce three indicators of the direction for innovation: increasing the range of products, expanding to new markets or increasing market share, and improving the quality of products. In the process innovation equation we include three indicators of the direction of innovation: improving the flexibility of production, increasing capacity, and lowering unit costs. We assume also that whether a firm prefers either of the IP methods is related to whether the innovation which is new to the market. Therefore, in the appropriability equations only, we introduce a dummy variable if the firm's innovation is new to the firm but not the market. We exclude the 
foreign ownership, exports, and the industry-level variables from the equations in Stage 2. Our assumption is that these drive the innovation or R\&D decision but do not predict innovation output once we control for the level of spending.

Stage 3. In the augmented production function, output is measured as sales while labour is measured by the number of employees, capital by the total stock of physical capital, constructed from the investment series using a $10 \%$ depreciation rate, and materials by purchased goods and services. We also include the predicted value of innovation output from the second stage, the formal and informal IP dummies, and their interactions with innovation outputs.

Table 1 gives descriptive statistics for the estimation sample, for all firms, the firms that have positive R\&D spending, and the larger set of firms with positive innovation spending. The first panel shows the medians and interquartile ranges for the continuous variables and the second panel shows the means for all the dummy variables. The median firm has 305 employees, value added of 9 million pounds sterling, and a capital stock of 5 million pounds sterling. On average, the firms are 28 years old and 25 per cent are foreign-owned, but 48 per cent export. 33 per cent of the firms have introduced products new to the firm or market in the past three years $(22$ per cent new to the market), and 26 per cent have introduced a process innovation during the same period (7 per cent new to the market). 35 per cent rate some form of formal IP of medium to high importance, whereas 45 per cent rate informal IP of medium to high importance.

In addition to R\&D spending, which has been well studied in the past, this paper also looks at the broader definition of innovation spending, which includes internal and external R\&D, purchase of new capital equipment for innovation, purchase of external knowledge, and marketing and, training expense associated with the introduction of new products and processes. Table 1 shows that the total of this spending is substantially larger than R\&D alone, and that more firms have non-zero expenditures. The median innovation expenditure per employee is 158 thousand pounds sterling. The R\&D-doing firms are higher on all the IP and innovation dimensions. They are also large, and have higher non-R\&D innovation expenditure, with a median that is five times the $R \& D$ median. When we add the firms that have other types of innovation expenditure to 
the R\&D-doing firms, the IP and innovation indicators generally fall, but are still higher than those for firms with no innovation expenditure at all.

Table 2 gives some information about the composition of innovation spending. By far the largest share of such spending is for the acquisition of machinery and computer hardware and software, especially in SMEs and service firms. Internal R\&D spending is a relatively small share (less than 20 per cent) of innovation spending, although it is somewhat more important for manufacturing firms. This confirms the fact that innovation in firms is a much broader concept than innovation associated with R\&D. We expect that process innovation and innovation in services in particular to be associated with the acquisition of new equipment and software, rather than with R\&D per se.

\section{BASIC RESULTS}

We present two versions of our estimates of the CDM model, one that uses $R \& D$ spending as the innovation input and one using the broader definition of innovation spending that includes $\mathrm{R} \& \mathrm{D}$, new capital equipment, and training and marketing associated with innovation. Table 3 shows estimates for both the R\&D and the innovation models. Tables $4 \mathrm{a}$ and $4 \mathrm{~b}$ show the innovation-IP equation estimates using $\mathrm{R} \& \mathrm{D}$ as an input, and Tables $6 \mathrm{a}$ and $6 \mathrm{~b}$ the corresponding estimates using innovation spending as an input. Finally, Tables 5 and 7 show the production function estimates for each model. In the next two subsections of the paper, we discuss the results that use R\&D as in input first, followed by those using innovation spending.

\section{R\&D spending}

The results from Table 3 show that the choice of a sample selection model with correlated disturbances is supported by the data: the correlation coefficient between the two equation disturbances is positive and quite significant. This implies that firms which invest in R\&D (even though they are not predicted to) also have higher R\&D than predicted. Firms in industries that rate formal appropriability mechanisms as of medium or high importance do invest more in R\&D, with a coefficient that implies a doubling of R\&D per employee, even in the presence of two-digit sector dummies. For 
informal IP methods, the coefficient is somewhat lower, but the confidence interval overlaps with that of formal IP methods.

Looking at the predictor variables, firms that invest in $R \& D$ are exporters, and if they export, their R\&D investment rate is about 65 per cent higher. Foreign-owned firms are slightly less likely to invest in $R \& D$, but when they do, they have a higher $R \& D$ investment rate, other things equal. The uses of different sources of information for innovation are generally positive for investing $R \& D$ and $R \& D$ intensity. Collaborating with other organizations and firms has a positive impact on doing R\&D and its intensity. As we control for two-digit industry, the sector-specific characteristics generally do not matter, with the exception of the attitudes toward IP protection, which has a positive impact on R\&D intensity.

Tables $4 \mathrm{a}$ and $4 \mathrm{~b}$ focus on the choice of the IP methods and on the innovation production function. The hypothesis that the type of innovation and the choice of IP methods are positively correlated conditional on the observables is confirmed by the data, with all correlations significantly positive, and ranging from 0.04 to 0.55 ; most are above 0.1 .

In general, the results for product and process innovators are quite similar but there are some important differences. Firms rating some form of IP highly are larger firms with high R\&D intensity and are likely both to rate demand uncertainty large and to consider themselves financially constrained. Firms that are imitators (that is, they produce innovations that are new to the firm but not to the market) rate formal IP of less importance, as we also found in Hall et al. (2013). Where the source of information for innovation is suppliers or competitors, firms tend to rate the use of formal and informal IP highly. However, when customers are the main source of information or the source is within group, they are less likely to consider formal IP mechanisms as important, which is perhaps not surprising. More surprising is the fact that firms collaborating for innovation are less likely to rate formal IP highly.

Turning to the innovation equations (third columns of Tables $4 \mathrm{a}$ and $4 \mathrm{~b}$ ), we observe that product innovators have a high predicted R\&D intensity from the previous stage of estimation but that process innovation appears to be less driven by R\&D. Larger firms 
are more likely to innovate, but innovation does not depend on firm age. Information internal to the firm's group is rated as important for innovation, and information from suppliers is important only for process innovation. It appears that meeting regulatory requirements or standards reduces the probability of innovation, and that reducing environmental impacts and improving health and safety increases the probability of process innovation. This may be because the results of innovative activities directed in this way are somewhat more predictable.

The estimates of the augmented production function are shown in Table 5, for four types of innovation: product, process, and new-to-the-market product and process. The coefficients of the usual production function inputs (labour, capital, and materials) are as expected, and imply a scale coefficient slightly greater than unity. Few of the innovation or IP coefficients are significant, with the exception of formal IP in the case of process innovation. However, when the coefficients are combined to identify the interaction of innovation probability with IP preferences, some highly significant results appear: for product innovation, formal IP coupled with high predicted innovation raises productivity by about 12 per cent (15 per cent for new-to-the-market innovation), whereas informal IP coupled with innovations has essentially no impact. For process innovation, there are similar results, although the precision is lower, especially for newto-the-market process innovation. The conclusion is that innovating firms that rate formal IP as important for protecting their innovations achieve a substantial gain in the contribution of their innovations to productivity growth.

\section{Innovation spending}

The estimates for the model using innovation spending as an input are presented in Tables 3, 6, and 7. Table 3 shows the results for the first stage (investment in innovation and innovation spending intensity) while Tables 6a (product) and 6b (process) shows the results for the two different innovation production functions and the choice of IP methods. Finally, Table 7 presents the estimates of the augmented production function.

Table 3 allows us to compare the estimates of a generalized Tobit model for innovation spending to those for R\&D investment alone. Note first that there does not seem to be any correlation between the unobserved propensity to spend on innovation and its 
level, conditional on all the firm characteristics in the model, in contrast to the R\&D model. Otherwise, the estimated coefficients are similar with a few exceptions. The most important is the difference in the sector's formal IP importance, which has little predictive power for innovation spending intensity and strong predictive power for $R \& D$. The other significant differences are in the information sources: information from within the group is a less important predictor of innovation spending, whereas information from suppliers flips sign and is a much more important predictor than it is for R\&D intensity. Both results undoubtedly reflect the importance of capital equipment spending as a component of the larger innovation spending variable. Innovation that depends on the acquisition of new hardware and software is less likely to be influenced by the importance of formal IP in the sector, and more dependent on information from the suppliers of that equipment.

Tables $6 \mathrm{a}$ and $6 \mathrm{~b}$ show relatively few differences from Tables $4 \mathrm{a}$ and $4 \mathrm{~b}$. That is, using innovation spending instead of $R \& D$ as a predictor of the preference for formal and informal IP and innovation makes little difference to the coefficient estimates. The largest differences statistically are the increase in the within group information source coefficients and the decrease in the suppliers information source coefficient. This may reflect the changes in these coefficients in the innovation spending equations, and raises some concern about the interpretation of these coefficients. That is, stronger coefficients in the innovation spending model seem to be reflected in strengthened coefficients of the opposite sign in the IP-innovation probability model. Recall that the latter model includes the value of R\&D or innovation spending that is predicted based partly on these coefficients.

The finding that there are few large differences between instrumenting innovation outcomes via R\&D spending or innovation spending suggests that the choice will probably make little difference to the predicted innovation probability and that is indeed the case, as we see in Table 7. There are essentially no differences in the estimates between Table 5 (which uses the R\&D model) and Table 7 (which uses the innovation spending model). The conclusion is that it makes no difference to the CDM model whether one uses R\&D spending or innovation spending as the innovation input, even though the two variables are in fact quite different for most firms. The correlation 
of the two variables is about 0.35 and approximately half of the firms with innovation expenditures have no R\&D spending. However, it is important to keep in mind that these variables are being instrumented, which means that what it really says is that the values of $R \& D$ and innovation spending predicted by size, age, industry, exporting, ownership, collaborating, the IP and regulation environment, and sources of information have the same impact on productivity. It is possible that our instruments are not sufficiently powerful to see a differential effect, although this is a bit surprising, especially in the case of process innovation, where we might have expected innovation spending to have greater impact than $R \& D$.

\section{SIZE AND SECTOR}

The previous results showed that firms favouring formal IP to protect their innovations have a productivity higher by 10-20 percent for the same set of inputs, but that favouring only informal IP did not have a similar impact. In this section we examine how this result varies over firm size and broad sector. To this end, we divide the sample into two groupings: 1) SMEs, defined as firms with fewer than 250 employees, and other (large) firms; 2) Manufacturing and Services, including construction, trade, utilities, and business services. The full R\&D model was re-estimated for both groupings and a summary of the results for the production function is shown in Tables 8 (size) and 9 (sector). ${ }^{12}$ Both groupings produced estimates with a slightly better fit than the pooled estimates.

Looking at Table 8, we first note that the IP variables enter productivity jointly significantly only for the SMEs, but not for the larger firms. However, looking at the individual coefficients, the earlier results on the importance of formal IP for productivity in the case of product innovation still holds for SMEs; equally, both informal and formal IP are important for the productivity of both SMEs and large firms in the case of product innovation. The most interesting result is that when we split the sample like this, we can see that informal IP protection is much more important for

\footnotetext{
${ }^{12}$ We also estimated the full innovation spending model, but as we saw earlier, it makes little difference for the productivity equation which model we use, so we do not show these estimates.
} 
large firm productivity than for SMEs, which is a somewhat surprising result. It can be rationalised in the light of the theoretical model of Anton and Yao (2004) who suggest that firms may be inclined to protect very valuable inventions (which may have a potential large impact on their productivity) with secrecy rather than with patents to avoid the risks of potential disclosure. That is, although the use of formal IP protection is more prevalent among large firms than among small firms (Hall et al. 2013), these firms also seem to find informal IP protection somewhat more useful for increasing their productivity than smaller firms. This may reflect the fact that SMEs have a greater need to access inputs external to the firm and therefore need to protect their knowledge more formally. Unlike large firms, SMEs may lack the necessary financial and human resources to engage in internal $R \& D$ and therefore they may tend to rely on external knowledge created by neighbouring firms (as well as universities) (Acs, Audretsch and Feldman, 1994) which makes necessary the use of formal IP mechanisms.

Turning to the sector-specific estimates in Table 9, we find first that the importance of formal IP over informal IP for productivity is supported strongly for the service sector, but much more ambiguously for the manufacturing sector, where informal IP is as important as formal IP and all the impact is negative. It turns out that this result is due primarily to the fact that a high probability of innovation in that sector is associated with substantially lower measured productivity, regardless of the firm's preference for IP protection. Further exploration did not turn up an explanation for this result. It may be due to the fact that there are longer lags between innovative activity and productivity in this sector, or to problems in measuring the inputs to productivity in innovative firms.

\section{CONCLUSIONS}

In this paper we have explored the estimation of an augmented CDM model that includes firm and industry ratings of the importance of various forms of intellectual property protection. Our main assumption was that the choice of a specific IP method does not necessarily affect a firm's productivity per se but does so through the type of innovation. Thus we modelled the choice of the appropriability mechanisms simultaneously with innovation success and then included the interaction of the choice 
with innovation in the productivity equation. We also explored the use of innovation spending rather than $\mathrm{R} \& \mathrm{D}$ as an innovation predictor, and took a brief look at the differences across firm size and sector.

There are a number of key results from this exploration. First, we found that firms who innovated and rated formal IP highly were more productive than other firms, but that the same did not hold for informal IP by itself, except possibly for large firms as opposed to SMEs. We also found that this result was strongest for firms in the services, trade, and utility sectors, and negative in the manufacturing sector, largely due to the negative impact of predicted innovation probability.

Second, we provide evidence that R\&D spending is only a fraction of total innovation spending, especially when we look beyond the manufacturing sector. However, the predictive power of the two types of spending for productivity is very similar, at least when we instrument the variables.

Third, we noted that in spite of the previous result, there were significant differences in the equations that predict $R \& D$ and innovation spending. $R \& D$ intensity is higher in exporting firms, those in formal IP sectors, and firms obtaining innovation information from within their group and from universities, whereas innovation spending is higher when suppliers are an important information source. This contrast appears to be one between the traditional technology-intensive sectors (patenting, exporting, and closer to university science) and innovation in sectors that rely on the acquisition of hardware and software to upgrade and change their processes.

Our study also suffers from a number of limitations. Most importantly, we found that predicted process and product innovation probabilities were so highly correlated that it is not really possible to tease out their separate impact in the same productivity equation, and we chose to analyse them separately to look for differences. We found relatively few differences, with the exception of a clear association of process innovation and information from suppliers. Second, the use of an IP importance rating as a proxy for IP use is somewhat untested, although we know they are related from our earlier work (Hall et al. 2013). A related problem is that the relationship between IP preferences and innovation is also rather imprecise, as the preference is based on the 
general outlook of the firm and the innovation(s) something that may have happened any time during the prior 3 years. That is, we do not have a precise measure of an innovation and the choice of IP for that innovation, only broad firm-level indicators.

Another limitation of this analysis, which we share with most studies using innovation data, is that it is conducted at the enterprise level, so that we cannot be sure that the answers to the questions on methods of IP protection are directly related to the innovation(s) identified by the firm as introduced during the preceding three years. Thus our data and our results are likely to contain considerable noise. In general this will weaken rather than strengthen the results, especially for the larger firms that have many activities.

Nor do we have an indicator of the quality of the innovation. This means that our finding of higher productivity when innovating firms favour formal IP protection may reflect the fact that firms with high quality innovations leading to higher productivity are also those more likely to use formal IP. The precise interpretation of our result matters, because if the formal IP-productivity relationship is due to higher quality, there is no implication that firms should shift to using formal IP, whereas if protecting any type of innovation with formal IP increases productivity, there would be such an implication. We leave the resolution of this conundrum to future work.

\section{References}

Acs, Z. J, Audretsch, D. B. and Feldman, M. P., 1994, R\&D Spillovers and Recipient Firm Size, The Review of Economics and Statistics, v. 76(2), 336-340.

Amara, N., R. Landry and N. Traore (2008). Managing the Protection of Innovations in Knowledge-Intensive Business Services. Research Policy, 37(9), 1530-47.

Anton, J. J. and D. A. Yao (2004). Little Patents and Big Secrets: Managing Intellectual Property, RAND Journal of Economics, 35(1), 1-22.

Arrow, K. J. (1962). Economic Welfare and the Allocation of Resources for Inventions" in Nelson, R. R. (ed.), The Rate and Direction of Inventive Activity: Economic and Social Factors. Princeton University Press. Princeton.

Arundel, A. (2001). The relative effectiveness of patents and secrecy for appropriation. Research Policy 30(4): 611-624. 
Arundel A. and I. Kabla (1998). What percentage of innovations are patented? empirical estimates for European firms. Research Policy. 27(2): 127-141.

Boldrin M. and D. K. Levine (2013). The Case Against Patents. Journal of Economic Perspectives. 27 (1): 3-22.

Bloom, N. and J. Van Reenen (2002). Patents, Real Options and Firm Performance. The Economic Journal, 112 (March), C97-C116.

Canepa, A. and P. Stoneman. (2008). Financial Constraints to Innovation in the UK: Evidence from CIS2 and CIS3, Oxford Economic Papers, 60(4), 711-730.

Cappellari, L. and S. P. Jenkins (2003). Multivariate Probit Regressions Using Simulated Maximum Likelihood, Stata Journal, 3(3), 278-294.

Czarniztki, D., B. H. Hall, and H. Hottenrott (2014). Patents as Quality Signals? The Implications for Financing Constraints on R\&D. Cambridge, MA: NBER Working Paper No. 19947.

Cohen, W. M., R. R. Nelson, and J. Walsh (2000). Protecting Their Intellectual Assets: Appropriability Conditions and Why U.S. Manufacturing Firms Patent (or Not). Cambridge, MA: NBER Working Paper No. 7552.

Cohen, W. N. and S. Klepper (1996). A reprise of Size and R\&D. The Economic Journal, 106 (437): 925-951.

Cohen, W. M. and R. C. Levin. (1989). Empirical Studies of Innovation and Market Structure. In R. Schamalensee \& Willig (eds.). Handbook of Industrial Organisations, 1059-1107. Amsterdam, Elsevier.

Crepon, B., E. Duguet, and J. Mairesse. (1998) Research, Innovation and Productivity: An Econometric Analysis at the Firm Level. Economics of Innovation and New Technology 7 (2): 115-58.

Crespi, G. and P. Zuniga. (2012) Innovation and Productivity: Evidence from Six Latin American Countries. World Development 40 (2): 273-90.

Gallini, N. T. (2002). The Economics of Patents: Lessons from Recent U.S. Patent Reform. Journal of Economic Perspectives 16(2): 131-154.

Girma, S. A. and H. B. Gorg. (2007). Multinationals' Productivity Advantage: Scale or Technology?. Economic Inquiry, 45(2), 350-362.

Griffith, R. E. Huergo, J. Mairesse, and B. Peters (2006). Innovation and Productivity Across Four European Countries. Oxford Review of Economic Policy 22(4): 483498.

Hall, B. (2002). The Financing of Research and Development. Oxford Review of Economic Policy, 18(1), 35-51. 
Hall, B. and J. Lerner. (2010). The Financing of R\&D and Innovation. MERIT Working Paper 012, United Nations University.

Hall, B. H., C. Helmers, M. Rogers, and V. Sena (2013). The importance (or not) of patents to UK firms. Oxford Economic Papers 65 (3): 603-629.

Hanel, P. (2005). Current Intellectual Property Protection Practices of Manufacturing Firms in Canada. In Intellectual Property and Innovation in the Knowledge-Based Economy, J. Putnam (ed.), Industry Canada.

Hanel, P. (2008). The use of intellectual property rights and innovation by manufacturing firms in Canada. Economics of Innovation and New Technology 17(4): 285-309.

Harabi, N. (1995). Appropriability of Technical Innovations: An Empirical Analysis. Research Policy, 24, 981-92.

Hipp C. B. and C. Herstatt (2006). Patterns of Innovation and Protection Activities within Service Companies. Results from a German Study on Service-intensive Companies. Working Paper 45, Technical University of Hamburg.

Howells, J., A. James and K. Malik. (2003), The Sourcing of Technological Knowledge: Distributed Innovation Processes and Dynamic Change. R\&D Management, 33(4), 395-409.

Hurmelinna-Laukkanen, P. and K. Puumalainen (2007). Nature and dynamics of appropriability: strategies for appropriating returns on innovation. $R \& D$ Management 37(2): 95-112.

Hussinger, K. (2006). Is silence golden? Patents versus secrecy at the firm level. Economics of Innovation and New Technology 15(8): 735-752.

Kamien, M, S. Oren and Y. Tauman. (1992). Optimal Licencing of Cost-reducing Innovations. Journal of Mathematical Economics, 21, 483-508.

Kultti, K., T. Takalo, and J. Toikka (2007). Secrecy versus Patenting. RAND Journal of Economics 38(1): 22-42.

Kumar, N. and a. Aggarwal (2005). Liberalisation, Outward Orientation and in-house R\&D Activity of Multinational and Local Firms: A Quantitative Exploration for Indian Manufacturing, Research Policy, 34(4), 441-460.

Leiponen, A. and Byma, J. (2009). If You cannot Block, You Better Run: Small Firms, Cooperative Innovation and Appropriation Strategies. Research Policy, 38, 147888.

Levin, R. C., A. K. Klevorick, R. R. Nelson, and S. G. Winter (1987). Appropriating the Returns from Industrial Research and Development. Brookings Papers on Economic Activity 3: 783-831. 
Laursen, K. and A. Salter (2005). My Precious - The Role of Appropriability Strategies in Shaping Innovative Performance. Working Paper 05-02, Danish Research Unit for Industrial Dynamics.

Mairesse, J. and Mohnen, P. (2003). Intellectual Property in Services. What do we learn from Innovation Surveys?. Patents Innovation and Economic Performance.

Morikawa, M. (2014). Innovation in the Service Sector and the Role of Patents and Trade Secrets, RIETI Discussion Paper 14-E-030.

Moser, P. (2013). Patents and Innovation: Evidence from Economic History. Journal of Economic Perspectives. 27 (1): 3-22.

Nordhaus, W. D. (1969). An Economic Theory of Technological Change. American Economic Review 59(2), 18-28.

Scellato, G. (2007). Patents, Firm Size and Financial Constraints: an Empirical Analysis for a Sample of Italian Manufacturing Firms, Cambridge Journal of Economics, 1, 55-76.

Teece, D. (1986). Profiting from Technological Innovation: Implications for Integration, Collaboration, Licencing and Public Policy. Research Policy, 15, 285-305.

Tiwari, A. K., P. Mohnen, F. C. Palm and S. S. Van der Loeff (2007). Financial Constraints and R\&D Investment: Evidence from CIS. UNU-Merit Working Paper 2007-011, United Nations University.

Zahra, S., Keil, T. and M. Maula, (2005). New ventures' inward licensing: examining the effects of industry and strategy characteristics. European Management Review, 2(3), 154-166. 


\section{Appendix A: Construction of the dataset}

For this study we have constructed an ad hoc dataset by using the following five components available at the SecureLab, UK Data Service. These are all linked by the unique reporting unit number:

Business Structure Database (BSD): the dataset is derived from the Inter Departmental Business Register (IDBR) and provides longitudinal business demography information for the population of businesses in the UK. We use information on a company's industrial classification (SIC 92) as well as incorporation and market exit dates from the BSD to be able to define the age of the firm. ${ }^{13}$

Annual Respondents Database (ARD2): the ARD2 is constructed from the microdata collected in the Annual Business Inquiry (ABI) conducted by the ONS. The stratified survey sample is drawn from the IDBR. $^{14}$ The ARD covers both the production (including manufacturing) and the non-production sector (services). However the time series dimension varies across the twos: while for the production sector it is possible to have information available up to 1980 (and early 70s for some industries), the data for the services sector is available only after 1997. The information is assembled from the replies to the Census forms: as this is a mandatory requirement for UK-based business, the response rates to the ARD are rather high and this makes it highly representative of the underlying population. Each establishment has got a unique reference number that does not change over time and so allows us to build up a panel dataset. The ARD is a stratified random sample where sampling probabilities are higher for large establishments: indeed for establishments with more than 250 employees, the sampling probability is equal to one. The ARD contains all the basic information (namely the inputs and output variables) needed to estimate the production function. Output is measured by the deflated added value. Employment is measured by the total number of

\footnotetext{
${ }^{13}$ The definition of market exit is problematic. It is not possible to identify whether a firm has ceased trading or if it has merely undergone a change in structure that leads to its original reference number becoming extinct.

${ }^{14}$ The stratification sample weights are as follows: businesses with (a) $<10$ employees 0.25 , (b) 10-99 employees 0.5 , (c) 100-249 employees all or $\geq 0.5$ depending on industry, and (d) $>250$ employees all. Moreover, if a firm with $<10$ employees is sampled once, it is not sampled again for at least three years.
} 
employees. As for capital, it is well known that the ARD does not contain information on capital stock. However, stock of capital has been constructed at the ONS by using the perpetual inventory method.

UK Community Innovation Survey (CIS) 3, 4, and 5: the CIS is a stratified sample of firms with more than 10 employees drawn from the IDBR. The CIS contains detailed information on firms' self-reported innovative activities. This covers firms' innovation activities over a three-year window targeting firms with more than ten employees. The CIS is a survey carried out by national statistical agencies in all $25 \mathrm{EU}$ member states under the coordination of Eurostat. The sampling frame for the UK CIS was developed from the Interdepartmental Business Register (IDBR) with the survey being conducted by post. Firms are asked whether they have produced any innovation in the reference period (i.e. the three years before the survey starts) and if so, what type of innovation they have introduced. In turn innovation can be of three types: product innovation, process innovation and wider (or organisational) innovation. Unsurprisingly, firms can be simultaneously produce two type of innovations (or even three types) and this allows us to construct our dependent variable as the total number of innovations produced by a firm over the period 2005-07. This variable can then vary between 0 (as firms may not produce any innovation in the reference period and therefore are recorded as non-innovators) and 3 (if firms produced a product, a process and a wider innovation at the same time). The CIS provides information on what external sources of information a firm uses and whether it collaborates with other organisations to develop innovation. In addition, the Survey contains information on $R \& D$ expenditure, the proportion of the workforce with a degree in engineering or a science subject and whether or not the plant is part of a group. We use three surveys: CIS 3 which covers the period 1998-2000, CIS 4 which covers 2002-2004, and CIS 5 which covers 2004-2006. The sample frames differ for the three CIS waves both in terms of size and industry coverage. For CIS 3, the sample frame consists of 19,625 enterprises with responses from 8,172 enterprises (42\% response rate); CIS 3 covers both production (manufacturing, mining, electricity, gas and water, construction) and services sectors whereas the retail sector has been excluded. CIS 4 has the largest sample size out of the three CIS waves with a sample frame of 28,355 enterprises and responses from 16,446 
enterprises (58\% response rate); it also includes the following sectors: sale, maintenance \& repair of motor vehicles (SIC 50); Retail Trade (SIC 52); and Hotels \& restaurants (SIC 55). CIS 5 was answered by 14,872 firms which correspond to a response rate of 53\% (Robson and Haigh, 2008). It covers the same industries as CIS 4 with the addition of SIC 921 (motion picture and video activities) and 922 (radio and television activities).

\section{Table A1: Choosing the sample}

\begin{tabular}{lrr}
\hline & Observations & Firms \\
\hline Total CIS observations & $\mathbf{6 8 , 1 1 2}$ & $\mathbf{4 6 , 6 3 8}$ \\
Not matched to ARD & 20,005 & \\
ARD-CIS match & $\mathbf{4 8 , 1 0 7}$ & \\
Drop missing industries, primary inds, inds 80-98 & 26,092 & \\
Drop non-profits, government, missing legal status & 519 & \\
Unable to construct capital stock & 5,040 & \\
Potential CIS sample & $\mathbf{1 6 , 4 5 6}$ & $\mathbf{1 1 , 4 2 1}$ \\
Missing employment on CIS & 1,049 & \\
Large estimation sample & $\mathbf{1 5 , 4 0 7}$ & $\mathbf{1 0 , 8 4 4}$ \\
Missing capital, turnover, or materials & 3,761 & \\
Trim ratios for production function at 1\% & $\mathbf{7 9 6}$ & \\
Estimation sample & $\mathbf{1 0 , 8 5 0}$ & $\mathbf{7 , 2 5 5}$ \\
\hline CIS 6 and 7 sample & $\mathbf{3 , 7 0 6}$ & $\mathbf{3 , 0 6 8}$ \\
CIS 3,4,5 sample & $\mathbf{7 , 1 4 4}$ & $\mathbf{5 , 5 5 3}$ \\
\hline
\end{tabular}


Table A2: Sectoral breakdown 1998-2010

\begin{tabular}{llrrrrr}
\hline & & Number of observations & \multicolumn{2}{c}{ Share } \\
SIC & Description & Total & Large & SMEs & Large & SMEs \\
\hline $23-25$, ex & & & & & & \\
244,245 & Mfg of chemical, rubber, plastic, oil & 445 & 267 & 178 & $60.0 \%$ & $40.0 \%$ \\
30,32 & Mfg of computers \& electronic inst & 156 & 80 & 76 & $51.3 \%$ & $48.7 \%$ \\
31 & Mfg of elec equipment & 192 & 92 & 100 & $47.9 \%$ & $52.1 \%$ \\
28 & Mfg of fabricated metal goods & 318 & 117 & 201 & $36.8 \%$ & $63.2 \%$ \\
15,16 & Mfg of food, beverage, and tobacco & 713 & 500 & 213 & $70.1 \%$ & $29.9 \%$ \\
33 & Mfg of medical \& scientific inst & 171 & 92 & 79 & $53.8 \%$ & $46.2 \%$ \\
$17-19,36$ & Mfg of misc low-tech goods & 502 & 237 & 265 & $47.2 \%$ & $52.8 \%$ \\
34 & Mfg of motor vehicales & 294 & 176 & 118 & $59.9 \%$ & $40.1 \%$ \\
29 & Mfg of non-elec machinery & 413 & 239 & 174 & $57.9 \%$ & $42.1 \%$ \\
35 & Mfg of other transport equipment & 188 & 98 & 90 & $52.1 \%$ & $47.9 \%$ \\
244 & Mfg of pharmaceuticals & 57 & 47 & 10 & $82.5 \%$ & $17.5 \%$ \\
26,27 & Mfg of primary metals & 301 & 153 & 148 & $50.8 \%$ & $49.2 \%$ \\
22 & Mfg of printed goods & 285 & 202 & 83 & $70.9 \%$ & $29.1 \%$ \\
245 & Mfg of soap \& toiletries & 61 & 46 & 15 & $75.4 \%$ & $24.6 \%$ \\
20,21 & Mfg of wood \& furniture & 243 & 97 & 146 & $39.9 \%$ & $60.1 \%$ \\
& Total manufacturing & 4339 & 2443 & 1896 & $56.3 \%$ & $43.7 \%$ \\
\hline 45 & Construction & 803 & 413 & 390 & $51.4 \%$ & $48.6 \%$ \\
64 & Post, telephone, and telegraph & 148 & 85 & 63 & $57.4 \%$ & $42.6 \%$ \\
$37,40,41,90$ & Utility services & 134 & 68 & 66 & $50.7 \%$ & $49.3 \%$ \\
$50-52$ & Wholesale \& retail trade & 2077 & 1372 & 705 & $66.1 \%$ & $33.9 \%$ \\
& Total utilites \& trade & 3162 & 1938 & $\mathbf{1 2 2 4}$ & $\mathbf{6 1 . 3 \%}$ & $\mathbf{3 8 . 7 \%}$ \\
\hline 72 & Computer services & 206 & 125 & 81 & $60.7 \%$ & $39.3 \%$ \\
$65-70$ & Financial, insurance, real estate & 286 & 181 & 105 & $63.3 \%$ & $36.7 \%$ \\
55 & Hotel \& restaurant services & 499 & 401 & 98 & $80.4 \%$ & $19.6 \%$ \\
71 & Leasing services & 163 & 72 & 91 & $44.2 \%$ & $55.8 \%$ \\
73,74 & Other business services & 1394 & 932 & 462 & $66.9 \%$ & $33.1 \%$ \\
\hline $60-63$ & R\&D services & 76 & 49 & 27 & $64.5 \%$ & $35.5 \%$ \\
\hline & Transportation services & 725 & 455 & 270 & $62.8 \%$ & $37.2 \%$ \\
& Total services & 3349 & 2215 & 1134 & $66.1 \%$ & $33.9 \%$ \\
\hline & Total & & & & & \\
& & 6596 & 4254 & $60.8 \%$ & $39.2 \%$ \\
\hline & & & & &
\end{tabular}


Table 1: Estimation sample - CIS 3, 4, 5 matched to BSD (2000-2006)

\begin{tabular}{|c|c|c|c|c|c|c|}
\hline \multirow[b]{2}{*}{ Variable } & \multicolumn{2}{|c|}{ All observations } & \multicolumn{2}{|c|}{$R \& D$ firms } & \multicolumn{2}{|c|}{ Inn. spend firms } \\
\hline & Median & IQ range & Median & IQ range & Median & IQ range \\
\hline Observations & \multicolumn{2}{|c|}{7,144} & \multicolumn{2}{|c|}{2,162} & \multicolumn{2}{|c|}{4,414} \\
\hline Number of employees & 305 & 627.5 & 353.5 & 763 & 315 & 607 \\
\hline Turnover* & 25000 & 71327 & 35811 & 89629 & 27385 & 73283 \\
\hline Value added* & 8951 & 21916 & 11729 & 25951 & 9748 & 22167 \\
\hline Capital* & 5002 & 15407 & 7572 & 19522 & 5661 & 16315 \\
\hline Purchased goods \& services* & 12014 & 39102 & 18794 & 42940 & 13490 & 39168 \\
\hline Output-employee ratio* & 85.87 & 93.85 & 94.82 & 87.81 & 89.52 & 93.68 \\
\hline Output-capital ratio & 5.22 & 10.49 & 4.69 & 8.30 & 5.02 & 10.21 \\
\hline Output-materials ratio & 1.80 & 2.25 & 1.75 & 1.87 & 1.76 & 2.19 \\
\hline Capital per employee* & 17.17 & 31.97 & 20.72 & 34.95 & 18.48 & 32.92 \\
\hline R\&D -turnover ratio & 0.0000 & 0.0004 & 0.0025 & 0.0092 & 0.0000 & 0.0024 \\
\hline Innovation spend -turnover ratio & 0.0019 & 0.0155 & 0.0142 & 0.0380 & 0.0104 & 0.0290 \\
\hline R\&D per employee* & 0.000 & 0.036 & 0.246 & 0.942 & 0.000 & 0.234 \\
\hline Innovation spend per employee* & 0.158 & 1.421 & 1.333 & 3.728 & 0.915 & 2.663 \\
\hline Age in 2011 in years & 28 & 18 & 29 & 17 & 28 & 18 \\
\hline Importance of formal IP in the 3-digit sector & 0.35 & 0.33 & 0.44 & 0.28 & 0.38 & 0.35 \\
\hline Importance of informal IP in the 3-digit sector & 0.40 & 0.36 & 0.59 & 0.31 & 0.48 & 0.36 \\
\hline Perception of market risk in the 3-digit sector & 0.37 & 0.34 & 0.40 & 0.24 & 0.38 & 0.29 \\
\hline Perception of financial constraints in the $3-d$ sector & 0.34 & 0.25 & 0.34 & 0.22 & 0.34 & 0.25 \\
\hline Importance of regulation \& standards in the 3-digit sector & 0.33 & 0.32 & 0.39 & 0.25 & 0.36 & 0.31 \\
\hline Importance of environmental, H\&S regs. in the 3-digit sector & 0.29 & 0.29 & 0.37 & 0.30 & 0.31 & 0.32 \\
\hline
\end{tabular}

* Units are 1000 s of GBP. 
Table 1 (cont.): Dummy variable means

\begin{tabular}{|c|c|c|c|}
\hline Variable & $\begin{array}{c}\text { All } \\
\text { observations }\end{array}$ & $R \& D$ firms & $\begin{array}{l}\text { Innov. spend } \\
\text { firms }\end{array}$ \\
\hline D (formal IP of med or high importance) & $35.1 \%$ & $62.3 \%$ & $46.7 \%$ \\
\hline D (informal IP of med or high importance) & $44.8 \%$ & $77.3 \%$ & $60.7 \%$ \\
\hline D (foreign ownership) & $25.0 \%$ & $29.4 \%$ & $26.3 \%$ \\
\hline D (export status) & $48.1 \%$ & $70.6 \%$ & $57.0 \%$ \\
\hline D (market risk) & $43.2 \%$ & $55.6 \%$ & $50.0 \%$ \\
\hline D (financial constraints) & $39.5 \%$ & $46.2 \%$ & $44.5 \%$ \\
\hline D (innov to improve range) & $39.2 \%$ & $64.8 \%$ & $52.0 \%$ \\
\hline D (innov for new markets) & $40.8 \%$ & $66.6 \%$ & $54.1 \%$ \\
\hline D (innov for quality improvement) & $47.3 \%$ & $73.7 \%$ & $62.4 \%$ \\
\hline D (innov to increase flexibility) & $37.1 \%$ & $57.6 \%$ & $49.0 \%$ \\
\hline D (innov to increase capacity) & $34.2 \%$ & $52.3 \%$ & $45.3 \%$ \\
\hline D (innov to reduce unit cost) & $37.2 \%$ & $59.9 \%$ & $49.3 \%$ \\
\hline D (innov to meet regulations or standards) & $34.3 \%$ & $50.7 \%$ & $43.7 \%$ \\
\hline D (innov for environment or health\&safety) & $31.0 \%$ & $49.0 \%$ & $40.3 \%$ \\
\hline D (collaborates) & $19.2 \%$ & $37.0 \%$ & $26.4 \%$ \\
\hline D (within group important info source) & $58.4 \%$ & $91.4 \%$ & $78.3 \%$ \\
\hline D (suppliers important info source) & $52.7 \%$ & $75.2 \%$ & $70.1 \%$ \\
\hline D (customers important info source) & $55.9 \%$ & $83.4 \%$ & $73.7 \%$ \\
\hline D (competitors important info source) & $41.9 \%$ & $62.0 \%$ & $54.8 \%$ \\
\hline D (universities important info source) & $10.3 \%$ & $20.8 \%$ & $14.1 \%$ \\
\hline D (product imitator only) & $11.0 \%$ & $19.6 \%$ & $15.8 \%$ \\
\hline $\mathrm{D}$ (product innovator) & $33.4 \%$ & $63.0 \%$ & $47.1 \%$ \\
\hline D (new-to-market product innovator) & $22.4 \%$ & $43.4 \%$ & $31.3 \%$ \\
\hline D (process imitator only) & $19.2 \%$ & $32.1 \%$ & $26.8 \%$ \\
\hline $\mathrm{D}$ (process innovator) & $26.4 \%$ & $46.8 \%$ & $37.2 \%$ \\
\hline $\mathrm{D}$ (new-to-market process innovator) & $7.2 \%$ & $14.7 \%$ & $10.4 \%$ \\
\hline
\end{tabular}


Table 2: Average composition of innovation expenditure

\begin{tabular}{|c|c|c|c|c|c|}
\hline & All & SME & Large & $\begin{array}{c}\text { Manu- } \\
\text { facturing }\end{array}$ & $\begin{array}{c}\text { Services \& } \\
\text { other }\end{array}$ \\
\hline Acquisition of mach. \& comp. hardware/software & $45.1 \%$ & $48.0 \%$ & $43.0 \%$ & $43.2 \%$ & $47.0 \%$ \\
\hline Internal R\&D spending & $18.6 \%$ & $17.7 \%$ & $19.2 \%$ & $25.1 \%$ & $12.0 \%$ \\
\hline Marketing expense & $13.5 \%$ & $11.8 \%$ & $14.9 \%$ & $10.6 \%$ & $16.5 \%$ \\
\hline Training expense & $9.5 \%$ & $10.2 \%$ & $8.9 \%$ & $5.4 \%$ & $13.4 \%$ \\
\hline Design expense & $6.4 \%$ & $5.9 \%$ & $6.8 \%$ & $8.8 \%$ & $4.2 \%$ \\
\hline External R\&D spending & $3.7 \%$ & $3.5 \%$ & $3.9 \%$ & $4.2 \%$ & $3.2 \%$ \\
\hline Acquisition of external knowledge & $3.2 \%$ & $2.9 \%$ & $3.4 \%$ & $2.6 \%$ & $3.7 \%$ \\
\hline Observations with nonzero spending & 4,414 & 1,876 & 2,538 & 2,199 & 2,215 \\
\hline Share with nonzero spending & $61.8 \%$ & $57.1 \%$ & $65.8 \%$ & $71.1 \%$ & $54.7 \%$ \\
\hline
\end{tabular}

The shares shown are for firms that have some form of innovation spending reported. 
Table 3: Sample selection estimates - Investment in R\&D or Innovation and its intensity

\begin{tabular}{|c|c|c|c|c|c|c|c|c|c|c|c|c|}
\hline \multirow{4}{*}{$\begin{array}{l}\text { Dependent variable } \\
\text { Log (number of employees) }\end{array}$} & \multicolumn{3}{|c|}{ Invests in $R \& D(1 / 0)$} & \multicolumn{3}{|c|}{$\log (R \& D /$ employee) } & \multicolumn{3}{|c|}{ Invests in innov (1/0) } & \multicolumn{3}{|c|}{ Log (IS/employee) } \\
\hline & \multirow{3}{*}{$\frac{\text { Coefficient }}{0.073}$} & & & \multirow{3}{*}{$\begin{array}{c}\text { Marginal } \\
\text { Effects } \\
-0.230\end{array}$} & \multirow{2}{*}{\multicolumn{2}{|c|}{ Standard Errors }} & \multirow{3}{*}{$\frac{\text { Coefficient }}{0.024}$} & \multirow{2}{*}{\multicolumn{2}{|c|}{ Standard Errors }} & \multirow{3}{*}{$\begin{array}{c}\text { Marginal } \\
\text { Effects } \\
-0.263\end{array}$} & \multirow{2}{*}{\multicolumn{2}{|c|}{ Standard Errors }} \\
\hline & & Standard & Errors & & & & & & & & & \\
\hline & & 0.013 & $* * *$ & & 0.033 & $* * *$ & & 0.011 & $*$ & & 0.021 & $* * *$ \\
\hline Log (firm age in 2011) & 0.011 & 0.056 & & -0.202 & 0.108 & & -0.077 & 0.051 & & -0.052 & 0.072 & \\
\hline D (foreign ownership) & -0.097 & 0.046 & $*$ & 0.320 & 0.087 & $* * *$ & -0.071 & 0.043 & & 0.291 & 0.061 & $* * *$ \\
\hline D (export status) & 0.314 & 0.045 & $* * *$ & 0.651 & 0.096 & $* * *$ & 0.163 & 0.042 & $* * *$ & 0.418 & 0.060 & $* * *$ \\
\hline D (collaborates) & 0.415 & 0.047 & $* * *$ & 0.475 & 0.091 & $* * *$ & 0.272 & 0.055 & $* * *$ & 0.393 & 0.057 & $* * *$ \\
\hline Importance of formal IP in the 3-digit sector & 0.256 & 0.170 & & 1.050 & 0.299 & $* * *$ & -0.284 & 0.165 & & 0.351 & 0.212 & \\
\hline Importance of informal IP in the 3-digit sector & 0.242 & 0.188 & & 0.637 & 0.315 & $*$ & 0.378 & 0.183 & $*$ & 0.710 & 0.231 & $* * *$ \\
\hline Perception of market risk in the 3-digit sector & 0.348 & 0.182 & & 0.017 & 0.292 & & 0.156 & 0.175 & & -0.017 & 0.212 & \\
\hline \multicolumn{13}{|l|}{ Perception of financial constraints in the 3 -digit } \\
\hline $\begin{array}{l}\text { Importance of regulation \& standards in the 3- } \\
\text { digit sector }\end{array}$ & 0.016 & 0.198 & & 0.427 & 0.354 & & 0.127 & 0.197 & & 0.150 & 0.250 & \\
\hline \multicolumn{12}{|l|}{ Importance of environmental, health \& safety } & \\
\hline $\mathrm{D}$ (within group important info source) & 1.026 & 0.059 & $* * *$ & 0.859 & 0.195 & $* * *$ & 0.790 & 0.045 & $* * *$ & 0.292 & 0.077 & $* * *$ \\
\hline D (suppliers important info source) & 0.044 & 0.048 & & -0.279 & 0.086 & $* *$ & 0.493 & 0.042 & $* * *$ & 0.326 & 0.060 & $* * *$ \\
\hline D (customers important info source) & 0.305 & 0.056 & $* * *$ & 0.392 & 0.112 & $* * *$ & 0.401 & 0.049 & $* * *$ & 0.145 & 0.068 & $*$ \\
\hline D (competitors important info source) & -0.072 & 0.046 & & 0.055 & 0.081 & & -0.026 & 0.048 & & 0.169 & 0.055 & $* *$ \\
\hline D (universities important info source) & 0.307 & 0.061 & $* * *$ & 0.410 & 0.097 & $* * *$ & 0.050 & 0.074 & & 0.238 & 0.071 & $* * *$ \\
\hline Year Dummies & \multicolumn{3}{|c|}{$51.8(0.000)^{* * *}$} & \multicolumn{3}{|c|}{$3.2(0.206)$} & \multicolumn{3}{|c|}{$39.5(0.000)^{* * *}$} & \multicolumn{3}{|c|}{$2.4(0.295)$} \\
\hline Two-digit sector dummies & \multicolumn{3}{|c|}{$101.6(0.000)^{* * *}$} & \multicolumn{3}{|c|}{$181.8(0.000)^{* * *}$} & \multicolumn{3}{|c|}{$34.7(0.093)^{*}$} & \multicolumn{3}{|c|}{$163.2(0.000)^{* * *}$} \\
\hline \multicolumn{4}{|l|}{ Correlation of the disturbances in the two equations } & 0.349 & 0.101 & $* *$ & & & & 0.064 & 0.043 & \\
\hline \multicolumn{4}{|l|}{ Standard error of log R\&D per employee residual } & 1.637 & 0.046 & $* * *$ & & & & 1.576 & 0.019 & $* * *$ \\
\hline Log likelihood & \multicolumn{6}{|c|}{-7097.7} & \multicolumn{6}{|c|}{-11696.9} \\
\hline Wald test for model (d.f.) & & & 914.7( & $3) * * *$ & & & & & 1082.7 & $43)^{* * *}$ & & \\
\hline Observations (nonzero share) & & & 7,144 & $30 \%)$ & & & & & 7144 & $62 \%)$ & & \\
\hline
\end{tabular}

Standard Errors robsut to heteroskedasticity, clustered by enterprise

The method of estimation is maximum likelihood on a generalized Tobit model. 
Table 4a. Multivariate Probit estimates of IP choice and product innovation

7,144 observations on 5,684 firms; Log likelihood $=-8967.1$

\begin{tabular}{|c|c|c|c|c|c|c|c|c|c|}
\hline \multirow[b]{3}{*}{ Log (predicted R\&D per employee) } & \multicolumn{3}{|c|}{ Formal IP methods } & \multicolumn{3}{|c|}{ Informal IP methods } & \multicolumn{3}{|c|}{$\begin{array}{l}\text { Product Innovator or } \\
\text { imitator }\end{array}$} \\
\hline & \multirow{2}{*}{$\begin{array}{l}\text { Coeff. } \\
0.843\end{array}$} & \multicolumn{2}{|c|}{ Std. err } & \multirow{2}{*}{$\begin{array}{c}\text { Coeff. } \\
0.638\end{array}$} & \multicolumn{2}{|c|}{ Std. err } & \multirow{2}{*}{$\begin{array}{c}\text { Coeff. } \\
0.304\end{array}$} & \multicolumn{2}{|c|}{ Std. err } \\
\hline & & 0.045 & $* * *$ & & 0.044 & $* * *$ & & 0.046 & $* * *$ \\
\hline Log (n of employees) & 0.321 & 0.016 & $* * *$ & 0.229 & 0.015 & $* * *$ & 0.116 & 0.015 & $* * *$ \\
\hline Log (firm age in 2011) & 0.132 & 0.054 & $*$ & 0.114 & 0.053 & $*$ & -0.057 & 0.057 & \\
\hline D (collaborates) & -0.191 & 0.052 & $* * *$ & -0.026 & 0.054 & & 0.428 & 0.053 & $* * *$ \\
\hline Firm perception of market risk & 0.324 & 0.043 & $* * *$ & 0.366 & 0.044 & $* * *$ & 0.172 & 0.044 & $* * *$ \\
\hline Firm perception of fin. Constraints & 0.123 & 0.043 & $* *$ & 0.293 & 0.044 & $* * *$ & 0.018 & 0.044 & \\
\hline Firm - impt. of reg \& standards & 0.140 & 0.050 & $* *$ & 0.121 & 0.052 & $*$ & -0.118 & 0.053 & $*$ \\
\hline Firm - impt. of env, H\&S regs & 0.052 & 0.051 & & 0.160 & 0.054 & $* *$ & -0.023 & 0.054 & \\
\hline D (innov to improve range) & & & & & & & 0.704 & 0.051 & $* * *$ \\
\hline D (innov for new markets) & & & & & & & 0.234 & 0.054 & $* * *$ \\
\hline D (innov for quality improvement) & & & & & & & 0.266 & 0.058 & $* * *$ \\
\hline D (within group impt info source) & -0.234 & 0.066 & $* * *$ & 0.096 & 0.064 & & 0.311 & 0.068 & $* * *$ \\
\hline D (suppliers important info source) & 0.289 & 0.047 & $* * *$ & 0.415 & 0.047 & $* * *$ & 0.123 & 0.051 & $*$ \\
\hline D (customers impt info source) & -0.127 & 0.054 & $*$ & 0.140 & 0.053 & $* *$ & 0.139 & 0.058 & $*$ \\
\hline D (competitors impt info source) & 0.173 & 0.045 & $* * *$ & 0.130 & 0.045 & $* *$ & -0.113 & 0.047 & $*$ \\
\hline D (universities impt info source) & 0.058 & 0.064 & & 0.049 & 0.071 & & -0.080 & 0.066 & \\
\hline D (imitator) & -0.270 & 0.060 & $* * *$ & -0.266 & 0.064 & $* * *$ & & & \\
\hline Year dummies (2) & \multicolumn{3}{|c|}{$65.4(0.000) * * *$} & \multicolumn{3}{|c|}{$80.1(0.000)^{* * *}$} & \multicolumn{3}{|c|}{$1.5(0.464)$} \\
\hline Two-digit sector dummies (25) & \multicolumn{3}{|c|}{$298.2(0.000)^{* * *}$} & \multicolumn{3}{|c|}{$105.4(0.000)^{* * *}$} & \multicolumn{3}{|c|}{$52.9(0.000)^{* * *}$} \\
\hline Wald test for model (d.f.) & \multicolumn{9}{|c|}{$5,322.1(125)^{* * *}$} \\
\hline Corr (formal IP, informal IP) & 0.548 & 0.019 & $* * *$ & & & & & & \\
\hline Corr (formal IP, innovation) & 0.197 & 0.026 & $* * *$ & & & & & & \\
\hline Corr (informal IP, innovation) & 0.236 & 0.026 & $* * *$ & & & & & & \\
\hline
\end{tabular}

Note: The method of estimation is maximum likelihood on a trivariate probit model. Standard Errors are clustered around the enterprise 
Table 4b. Multivariate Probit estimates of IP choice and process innovation

7,144 observations on 5,684 firms; Log likelihood $=-8,959.6$

\begin{tabular}{|c|c|c|c|c|c|c|c|c|c|}
\hline \multirow[b]{3}{*}{ Log (predicted R\&D per employee) } & \multicolumn{3}{|c|}{ Formal IP methods } & \multicolumn{3}{|c|}{ Informal IP methods } & \multicolumn{3}{|c|}{$\begin{array}{l}\text { Process Innovator or } \\
\text { imitator }\end{array}$} \\
\hline & \multirow{2}{*}{$\begin{array}{l}\text { Coeff. } \\
0.843\end{array}$} & \multicolumn{2}{|c|}{ Std. err } & \multirow{2}{*}{$\begin{array}{l}\text { Coeff. } \\
0.636\end{array}$} & \multicolumn{2}{|c|}{ Std. err } & \multirow{2}{*}{$\begin{array}{l}\text { Coeff. } \\
0.100\end{array}$} & \multicolumn{2}{|c|}{ Std. err } \\
\hline & & 0.045 & $* * *$ & & 0.044 & $* * *$ & & 0.046 & $*$ \\
\hline Log (n of employees) & 0.321 & 0.016 & $* * *$ & 0.228 & 0.015 & $* * *$ & 0.085 & 0.016 & $* * *$ \\
\hline Log (firm age in 2011) & 0.136 & 0.055 & $*$ & 0.116 & 0.053 & $*$ & 0.015 & 0.057 & \\
\hline D (collaborates) & -0.201 & 0.052 & $* * *$ & -0.038 & 0.054 & & 0.573 & 0.052 & $* * *$ \\
\hline Firm perception of market risk & 0.322 & 0.043 & $* * *$ & 0.365 & 0.044 & $* * *$ & 0.119 & 0.044 & $* *$ \\
\hline Firm perception of fin. Constraints & 0.121 & 0.043 & $* *$ & 0.292 & 0.044 & $* * *$ & 0.016 & 0.043 & \\
\hline Firm - impt. of reg \& standards & 0.144 & 0.050 & $* *$ & 0.122 & 0.052 & $*$ & -0.183 & 0.053 & $* * *$ \\
\hline Firm - impt. of env, H\&S regs & 0.046 & 0.051 & & 0.157 & 0.054 & $* *$ & 0.161 & 0.054 & $* *$ \\
\hline D (innov to increase flexibility) & & & & & & & 0.480 & 0.055 & $* * *$ \\
\hline D (innov to increase capacity) & & & & & & & 0.408 & 0.053 & $* * *$ \\
\hline D (innov to reduce unit cost) & & & & & & & 0.180 & 0.054 & $* * *$ \\
\hline D (within group impt info source) & -0.240 & 0.066 & $* * *$ & 0.089 & 0.064 & & 0.471 & 0.072 & $* * *$ \\
\hline D (suppliers important info source) & 0.287 & 0.047 & $* * *$ & 0.413 & 0.047 & $* * *$ & 0.319 & 0.051 & $* * *$ \\
\hline D (customers impt info source) & -0.136 & 0.055 & $*$ & 0.129 & 0.053 & $*$ & 0.032 & 0.059 & \\
\hline D (competitors impt info source) & 0.169 & 0.045 & $* * *$ & 0.129 & 0.045 & $* *$ & -0.109 & 0.047 & $*$ \\
\hline D (universities impt info source) & 0.068 & 0.064 & & 0.066 & 0.071 & & -0.113 & 0.064 & \\
\hline $\mathrm{D}$ (imitator) & -0.084 & 0.056 & & -0.054 & 0.064 & & & & \\
\hline Year dummies (2) & \multicolumn{3}{|c|}{$65.4(0.000)^{* * *}$} & \multicolumn{3}{|c|}{$80.1(0.000)^{* * *}$} & \multicolumn{3}{|c|}{$21.1(0.000)^{* * *}$} \\
\hline Two-digit sector dummies (25) & \multicolumn{3}{|c|}{$298.2(0.000)^{* * *}$} & \multicolumn{3}{|c|}{$105.4(0.000)^{* * *}$} & \multicolumn{3}{|c|}{$45.2(0.000)^{* * *}$} \\
\hline Wald test for model (d.f.) & \multicolumn{9}{|c|}{$5,115.5(125)^{* * *}$} \\
\hline Corr (formal IP, informal IP) & 0.547 & 0.019 & $* * *$ & & & & & & \\
\hline Corr (formal IP, innovation) & 0.039 & 0.024 & & & & & & & \\
\hline Corr (informal IP, innovation) & 0.125 & 0.024 & $* * *$ & & & & & & \\
\hline
\end{tabular}

Note: The method of estimation is maximum likelihood on a trivariate probit model. Standard Errors are robust to heteroskedasticity, and clustered on enterprise. 
Table 5. OLS Estimates of the production function

\begin{tabular}{|c|c|c|c|c|c|c|c|c|c|c|c|c|}
\hline \multirow{4}{*}{$\begin{array}{l}\text { Dependent variable } \\
\text { Type of innovation } \\
\text { Log (n of employees) }\end{array}$} & \multicolumn{12}{|c|}{ Log (turnover) } \\
\hline & \multicolumn{3}{|c|}{ Product innovation } & \multicolumn{3}{|c|}{ Process innovation } & \multicolumn{3}{|c|}{$\begin{array}{c}\text { New-to-market product } \\
\text { innovation }\end{array}$} & \multicolumn{3}{|c|}{$\begin{array}{c}\text { New-to-market process } \\
\text { innovation }\end{array}$} \\
\hline & \multirow{2}{*}{$\begin{array}{l}\text { Coeff. } \\
0.664\end{array}$} & \multicolumn{2}{|c|}{ Std. err } & \multirow{2}{*}{$\begin{array}{l}\text { Coeff. } \\
0.664\end{array}$} & \multicolumn{2}{|c|}{ Std. err } & \multirow{2}{*}{$\begin{array}{c}\text { Coeff. } \\
0.663\end{array}$} & \multicolumn{2}{|c|}{ Std. err } & \multirow{2}{*}{$\begin{array}{c}\text { Coeff. } \\
0.664\end{array}$} & \multicolumn{2}{|c|}{ Std. err } \\
\hline & & 0.011 & $* * *$ & & 0.011 & $* * *$ & & 0.011 & $* * *$ & & 0.011 & $* * *$ \\
\hline Log (capital) & 0.096 & 0.007 & $* * *$ & 0.097 & 0.007 & $* * *$ & 0.096 & 0.007 & $* * *$ & 0.096 & 0.007 & $* * *$ \\
\hline Log (materials) & 0.276 & 0.010 & $* * *$ & 0.277 & 0.010 & $* * *$ & 0.276 & 0.010 & $* * *$ & 0.277 & 0.010 & $* * *$ \\
\hline Scale coefficient\# & 1.036 & 0.006 & $* * *$ & 1.038 & 0.006 & $* * *$ & 1.035 & 0.006 & $* * *$ & 1.037 & 0.006 & $* * *$ \\
\hline Predicted prob of innovation & 0.000 & 0.050 & & -0.105 & 0.056 & & 0.054 & 0.069 & & -0.256 & 0.180 & \\
\hline D (formal IP important)*Pred P of innov & -0.007 & 0.038 & & -0.012 & 0.034 & & 0.022 & 0.032 & & 0.013 & 0.027 & \\
\hline D (informal IP important)*Pred P of innov & 0.028 & 0.034 & & 0.035 & 0.032 & & 0.025 & 0.029 & & 0.030 & 0.025 & \\
\hline D (formal IP important) & 0.121 & 0.066 & & 0.191 & 0.076 & $*$ & 0.077 & 0.075 & & 0.416 & 0.186 & $*$ \\
\hline D (informal IP important) & -0.006 & 0.070 & & 0.019 & 0.080 & & -0.020 & 0.083 & & 0.088 & 0.216 & \\
\hline Prob innov and formal IP & 0.114 & 0.055 & $* *$ & 0.074 & 0.068 & & 0.153 & 0.075 & $* *$ & 0.173 & 0.216 & \\
\hline Prob innov and informal IP & 0.022 & 0.041 & & -0.051 & 0.051 & & 0.059 & 0.054 & & -0.138 & 0.157 & \\
\hline Prob innov and both & 0.136 & 0.031 & $* * *$ & 0.128 & 0.029 & $* * *$ & 0.158 & 0.038 & $* * *$ & 0.291 & 0.105 & $* * *$ \\
\hline F-test for 4 IP variables & \multicolumn{3}{|c|}{$3.6(0.009)^{* * *}$} & \multicolumn{3}{|c|}{$6.6(0.009)^{* * *}$} & \multicolumn{3}{|c|}{$2.6(0.037)^{* *}$} & \multicolumn{3}{|c|}{$5.6(0.009)^{* * *}$} \\
\hline F-test for 2 survey dummies & \multicolumn{3}{|c|}{$36.0(0.000)^{* * *}$} & \multicolumn{3}{|c|}{$34.2(0.000)^{* * *}$} & \multicolumn{3}{|c|}{$35.6(0.000)^{* * *}$} & \multicolumn{3}{|c|}{$34.0(0.000)^{* * *}$} \\
\hline F-test for 25 industry dummies & \multicolumn{3}{|c|}{$22.1(0.000)^{* * *}$} & \multicolumn{3}{|c|}{$22.3(0.000)^{* * *}$} & \multicolumn{3}{|c|}{$21.8(0.000)^{* * *}$} & \multicolumn{3}{|c|}{$22.0(0.000)^{* * *}$} \\
\hline F-test for model $(\mathrm{df}=35)$ & \multicolumn{3}{|c|}{$1360.9(0.000)^{* * *}$} & \multicolumn{3}{|c|}{$1357.5(0.000)^{* * *}$} & \multicolumn{3}{|c|}{$1357.7(0.000)^{* * *}$} & \multicolumn{3}{|c|}{$1357.2(0.000)^{* * *}$} \\
\hline R-squared & \multicolumn{3}{|c|}{0.902} & \multicolumn{3}{|c|}{0.902} & & 0.902 & & & 0.902 & \\
\hline SSR & & 572.9 & & &, 571.7 & & & 573.4 & & & 572.4 & \\
\hline Standard error & & 0.602 & & & 0.602 & & & .602 & & & 0.602 & \\
\hline
\end{tabular}

Standard errors robust to heteroskedasticity, clustered on firm.

Shaded coefficients are derived from the estimated coefficients.

7,144 observations on 5,684 firms.

\# Test is for the scale coefficient equal to unity 
Table 6a. Multivariate Probit estimates of IP choice and product innovation

7,144 observations on 5,684 firms; Log likelihood $=-9,005.1$

\begin{tabular}{|c|c|c|c|c|c|c|c|c|c|}
\hline \multirow[b]{3}{*}{ Log (predicted IS per employee) } & \multicolumn{3}{|c|}{ Formal IP methods } & \multicolumn{3}{|c|}{ Informal IP methods } & \multicolumn{3}{|c|}{$\begin{array}{l}\text { Product Innovator or } \\
\text { imitator }\end{array}$} \\
\hline & \multirow{2}{*}{$\begin{array}{l}\text { Coeff. } \\
1.026\end{array}$} & \multicolumn{2}{|c|}{ Std. err } & \multirow{2}{*}{$\begin{array}{l}\text { Coeff. } \\
0.945\end{array}$} & \multicolumn{2}{|c|}{ Std. err } & \multirow{2}{*}{$\begin{array}{c}\text { Coeff. } \\
0.453\end{array}$} & \multicolumn{2}{|c|}{ Std. err } \\
\hline & & 0.065 & $* * *$ & & 0.063 & $* * *$ & & 0.066 & $* * *$ \\
\hline Log ( $n$ of employees) & 0.399 & 0.020 & $* * *$ & 0.329 & 0.019 & $* * *$ & 0.165 & 0.020 & $* * *$ \\
\hline Log (firm age in 2011) & 0.028 & 0.053 & & 0.042 & 0.053 & & -0.092 & 0.056 & \\
\hline D (collaborates) & -0.182 & 0.054 & $* * *$ & -0.093 & 0.056 & & 0.395 & 0.055 & $* * *$ \\
\hline Firm perception of market risk & 0.331 & 0.043 & $* * *$ & 0.373 & 0.044 & $* * *$ & 0.175 & 0.044 & $* * *$ \\
\hline Firm perception of fin. Constraints & 0.092 & 0.042 & $*$ & 0.270 & 0.044 & $* * *$ & 0.007 & 0.044 & \\
\hline Firm - impt. of reg \& standards & 0.151 & 0.050 & $* *$ & 0.131 & 0.052 & $*$ & -0.114 & 0.053 & $*$ \\
\hline Firm - impt. of env, H\&S regs & 0.030 & 0.051 & & 0.142 & 0.054 & $* *$ & -0.031 & 0.054 & \\
\hline D (innov to improve range) & & & & & & & 0.704 & 0.051 & $* * *$ \\
\hline D (innov for new markets) & & & & & & & 0.234 & 0.054 & $* * *$ \\
\hline D (innov for quality improvement) & & & & & & & 0.266 & 0.058 & $* * *$ \\
\hline D (within group impt info source) & 0.204 & 0.055 & $* * *$ & 0.372 & 0.054 & & 0.441 & 0.058 & $* * *$ \\
\hline D (suppliers important info source) & -0.288 & 0.048 & $* * *$ & -0.067 & 0.048 & & -0.108 & 0.051 & $*$ \\
\hline D (customers impt info source) & 0.054 & 0.052 & & 0.250 & 0.051 & $* * *$ & 0.191 & 0.056 & $* * *$ \\
\hline D (competitors impt info source) & 0.048 & 0.046 & & 0.007 & 0.046 & & -0.173 & 0.049 & $* * *$ \\
\hline D (universities impt info source) & 0.167 & 0.062 & $* *$ & 0.086 & 0.070 & & -0.063 & 0.065 & \\
\hline D (imitator) & -0.282 & 0.059 & $* * *$ & -0.275 & 0.064 & $* * *$ & & & \\
\hline Year dummies (2) & \multicolumn{3}{|c|}{$65.4(0.000) * * *$} & \multicolumn{3}{|c|}{$80.1(0.000)^{* * *}$} & \multicolumn{3}{|c|}{$1.5(0.464)$} \\
\hline Two-digit sector dummies (25) & \multicolumn{3}{|c|}{$298.2(0.000) * * *$} & \multicolumn{3}{|c|}{$105.4(0.000)^{* * *}$} & \multicolumn{3}{|c|}{$52.9(0.000)^{* * *}$} \\
\hline Wald test for model (d.f.) & \multicolumn{9}{|c|}{$5,269.2(125)^{* * *}$} \\
\hline Corr (formal IP, informal IP) & 0.553 & 0.019 & $* * *$ & & & & & & \\
\hline Corr (formal IP, innovation) & 0.202 & 0.026 & $* * *$ & & & & & & \\
\hline Corr (informal IP, innovation) & 0.237 & 0.026 & $* * *$ & & & & & & \\
\hline
\end{tabular}

Note: The method of estimation is maximum likelihood on a trivariate probit model. Standard Errors are clustered around the enterprise 
Table 6b. Multivariate Probit estimates of IP choice and process innovation

7,144 observations on 5,684 firms; Log likelihood $=-8,994.8$

\begin{tabular}{|c|c|c|c|c|c|c|c|c|c|}
\hline \multirow[b]{3}{*}{ Log (predicted IS per employee) } & \multicolumn{3}{|c|}{ Formal IP methods } & \multicolumn{3}{|c|}{ Informal IP methods } & \multicolumn{3}{|c|}{$\begin{array}{l}\text { Process Innovator or } \\
\text { imitator }\end{array}$} \\
\hline & \multirow{2}{*}{$\begin{array}{l}\text { Coeff. } \\
1.025\end{array}$} & \multicolumn{2}{|c|}{ Std. err } & \multirow{2}{*}{$\begin{array}{l}\text { Coeff. } \\
0.936\end{array}$} & \multicolumn{2}{|c|}{ Std. err } & \multirow{2}{*}{$\begin{array}{l}\text { Coeff. } \\
0.139\end{array}$} & \multicolumn{2}{|c|}{ Std. err } \\
\hline & & 0.065 & $* * *$ & & 0.064 & $* * *$ & & 0.066 & $*$ \\
\hline Log ( $n$ of employees) & 0.400 & 0.020 & $* * *$ & 0.327 & 0.020 & $* * *$ & 0.098 & 0.021 & $* * *$ \\
\hline Log (firm age in 2011) & 0.036 & 0.054 & & 0.045 & 0.053 & & 0.002 & 0.056 & \\
\hline D (collaborates) & -0.172 & 0.054 & $* *$ & -0.110 & 0.057 & & 0.567 & 0.054 & $* * *$ \\
\hline Firm perception of market risk & 0.336 & 0.043 & $* * *$ & 0.371 & 0.044 & $* * *$ & 0.120 & 0.044 & $* *$ \\
\hline Firm perception of fin. Constraints & 0.090 & 0.042 & $*$ & 0.267 & 0.044 & $* * *$ & 0.012 & 0.043 & \\
\hline Firm - impt. of reg \& standards & 0.153 & 0.050 & $* *$ & 0.133 & 0.052 & $*$ & -0.183 & 0.054 & $* * *$ \\
\hline Firm - impt. of env, H\&S regs & 0.042 & 0.051 & & 0.133 & 0.054 & $*$ & 0.159 & 0.056 & $* *$ \\
\hline D (innov to increase flexibility) & & & & & & & 0.482 & 0.056 & $* * *$ \\
\hline D (innov to increase capacity) & & & & & & & 0.410 & 0.053 & $* * *$ \\
\hline D (innov to reduce unit cost) & & & & & & & 0.176 & 0.054 & $* * *$ \\
\hline D (within group impt info source) & 0.213 & 0.056 & $* * *$ & 0.358 & 0.054 & $* * *$ & 0.516 & 0.062 & $* * *$ \\
\hline D (suppliers important info source) & -0.271 & 0.048 & $* * *$ & -0.070 & 0.048 & & 0.247 & 0.052 & $* * *$ \\
\hline D (customers impt info source) & 0.041 & 0.052 & & 0.237 & 0.051 & $* * *$ & 0.049 & 0.057 & \\
\hline D (competitors impt info source) & 0.041 & 0.046 & & 0.008 & 0.046 & & -0.127 & 0.049 & $* *$ \\
\hline D (universities impt info source) & 0.169 & 0.063 & $* *$ & 0.110 & 0.071 & & -0.104 & 0.063 & \\
\hline D (imitator) & -0.197 & 0.061 & $* * *$ & 0.042 & 0.065 & & & & \\
\hline Year dummies (2) & \multicolumn{3}{|c|}{$65.4(0.000)^{* * *}$} & \multicolumn{3}{|c|}{$80.1(0.000)^{* * *}$} & \multicolumn{3}{|c|}{$21.1(0.000)^{* * *}$} \\
\hline Two-digit sector dummies (25) & \multicolumn{3}{|c|}{$298.2(0.000)^{* * *}$} & \multicolumn{3}{|c|}{$105.4(0.000)^{* * *}$} & \multicolumn{3}{|c|}{$45.2(0.000)^{* * *}$} \\
\hline Wald test for model (d.f.) & \multicolumn{9}{|c|}{$5,042.8(125)^{* * *}$} \\
\hline Corr (formal IP, informal IP) & 0.556 & 0.018 & $* * *$ & & & & & & \\
\hline Corr (formal IP, innovation) & 0.105 & 0.032 & $* * *$ & & & & & & \\
\hline Corr (informal IP, innovation) & 0.118 & 0.033 & $* * *$ & & & & & & \\
\hline
\end{tabular}

Note: The method of estimation is maximum likelihood on a trivariate probit model. Standard Errors are robust to heteroskedasticity, and clustered on enterprise. 
Table 7. OLS Estimates of the production function - innovation spending model

\section{Dependent variable}

Type of innovation

Standard errors robust to heteroskedasticity, clustered on firm.

Shaded coefficients are derived from the estimated coefficients.

7,144 observations on 5,684 firms.

\# Test is for the scale coefficient equal to unity

\begin{tabular}{lcc} 
Type of innovation & \multicolumn{3}{c}{ Product innovation } \\
\hline & Coeff. & Std. err \\
\hline Log (n of employees) & 0.664 & 0.011 \\
Log (capital) & 0.096 & 0.007 \\
Log (materials) & 0.276 & 0.010 \\
\hline Scale coefficient\# & 1.036 & 0.006 \\
\hline Predicted prob of innovation & 0.003 & 0.051 \\
D (formal IP important)*Pred P of innov & -0.009 & 0.037 \\
D (informal IP important)*Pred P of innov & 0.028 & 0.034 \\
D (formal IP important) & 0.126 & 0.066 \\
D (informal IP important) & -0.008 & 0.070 \\
\hline Prob innov and formal IP & 0.120 & 0.056 \\
Prob innov and informal IP & 0.023 & 0.041 \\
Prob innov and both & 0.140 & 0.031 \\
\hline F-test for 4 IP variables & \multicolumn{2}{|c}{$3.7(0.006)^{* * *}$} \\
F-test for 2 survey dummies & $36.0(0.000)^{* * *}$ \\
F-test for 25 industry dummies & $22.1(0.000)^{* * *}$ \\
F-test for model (df=35) & $1361.4(0.000)^{* * *}$ \\
R-squared & \multicolumn{2}{c}{0.902} \\
SSR & \multicolumn{2}{c}{$2,572.7$} \\
Standard error & 0.602 \\
\hline \hline
\end{tabular}

\section{Log (turnover)}

New-to-market product New-to-market process

Process innovation

\begin{tabular}{llllllllll} 
& Coeff. & \multicolumn{2}{c}{ Std. err } & Coeff. & \multicolumn{2}{c}{ Std. err } & Coeff. & \multicolumn{2}{c}{ Std. err } \\
$* * *$ & 0.664 & 0.011 & $* * *$ & 0.663 & 0.011 & $* * *$ & 0.664 & 0.011 & $* * *$ \\
$* * *$ & 0.097 & 0.007 & $* * *$ & 0.096 & 0.007 & $* * *$ & 0.096 & 0.007 & $* * *$ \\
$* * *$ & 0.277 & 0.010 & $* * *$ & 0.276 & 0.010 & $* * *$ & 0.277 & 0.010 & $* * *$ \\
\hline$* * *$ & 1.038 & 0.006 & $* * *$ & 1.035 & 0.006 & $* * *$ & 1.037 & 0.006 & $* * *$ \\
\hline & & & & & & & & & \\
& -0.107 & 0.056 & & 0.048 & 0.069 & & -0.282 & 0.180 & \\
& -0.013 & 0.034 & & 0.019 & 0.032 & & 0.012 & 0.027 & \\
& 0.035 & 0.032 & & 0.026 & 0.029 & & 0.030 & 0.025 & \\
& 0.194 & 0.076 & $*$ & 0.088 & 0.075 & & 0.433 & 0.186 & $*$ \\
& 0.020 & 0.080 & & -0.022 & 0.084 & & 0.093 & 0.216 & \\
$* *$ & 0.074 & 0.068 & & 0.155 & 0.076 & $* *$ & 0.163 & 0.216 & \\
& -0.052 & 0.051 & & 0.052 & 0.054 & & -0.159 & 0.156 & \\
$* * *$ & 0.129 & 0.031 & $* * *$ & 0.159 & 0.038 & $* * *$ & 0.286 & 0.105 & $* * *$ \\
\hline
\end{tabular}

innovation

\begin{tabular}{llllllllll} 
& Coeff. & \multicolumn{2}{c}{ Std. err } & Coeff. & \multicolumn{2}{c}{ Std. err } & Coeff. & \multicolumn{2}{c}{ Std. err } \\
$* * *$ & 0.664 & 0.011 & $* * *$ & 0.663 & 0.011 & $* * *$ & 0.664 & 0.011 & $* * *$ \\
$* * *$ & 0.097 & 0.007 & $* * *$ & 0.096 & 0.007 & $* * *$ & 0.096 & 0.007 & $* * *$ \\
$* * *$ & 0.277 & 0.010 & $* * *$ & 0.276 & 0.010 & $* * *$ & 0.277 & 0.010 & $* * *$ \\
\hline$* * *$ & 1.038 & 0.006 & $* * *$ & 1.035 & 0.006 & $* * *$ & 1.037 & 0.006 & $* * *$ \\
\hline & & & & & & & & & \\
& -0.107 & 0.056 & & 0.048 & 0.069 & & -0.282 & 0.180 & \\
& -0.013 & 0.034 & & 0.019 & 0.032 & & 0.012 & 0.027 & \\
& 0.035 & 0.032 & & 0.026 & 0.029 & & 0.030 & 0.025 & \\
& 0.194 & 0.076 & $*$ & 0.088 & 0.075 & & 0.433 & 0.186 & $*$ \\
& 0.020 & 0.080 & & -0.022 & 0.084 & & 0.093 & 0.216 & \\
$* *$ & 0.074 & 0.068 & & 0.155 & 0.076 & $* *$ & 0.163 & 0.216 & \\
& -0.052 & 0.051 & & 0.052 & 0.054 & & -0.159 & 0.156 & \\
$* * *$ & 0.129 & 0.031 & $* * *$ & 0.159 & 0.038 & $* * *$ & 0.286 & 0.105 & $* * *$ \\
\hline
\end{tabular}

innovation

$6.7(0.009)^{* * *}$
$34.2(0.000)^{* * *}$
$22.3(0.000)^{* * *}$
$1357.6(0.000)^{* * *}$
0.902
$2,571.6$
0.601

\begin{tabular}{c}
$2.7(0.027)^{* *}$ \\
$35.5(0.000)^{* * *}$ \\
$21.7(0.000)^{* * *}$ \\
$1357.7(0.000)^{* * *}$ \\
0.902 \\
$2,573.4$ \\
0.602 \\
\hline
\end{tabular}
$5.9(0.000)^{* * *}$ $33.7(0.000)^{* * *}$ $22.1(0.000) * * *$ $1357.2(0.000)^{* * *}$ 0.902
$2,572.2$ 0.602

.


Table 8: Estimates of the production function by firm size

\begin{tabular}{|c|c|c|c|c|c|c|c|c|c|c|c|c|c|c|c|c|}
\hline \multirow{4}{*}{$\begin{array}{l}\text { Dependent variable } \\
\text { Type of innovation } \\
\text { Log (capital) }\end{array}$} & \multicolumn{16}{|c|}{ Log (turnover) } \\
\hline & \multicolumn{8}{|c|}{ Product } & \multicolumn{8}{|c|}{ Process } \\
\hline & \multicolumn{3}{|c|}{ SMES } & \multicolumn{3}{|c|}{ Large firms } & \multicolumn{2}{|c|}{ T-test\# } & \multicolumn{3}{|c|}{ SMES } & \multicolumn{3}{|c|}{ Large firms } & \multicolumn{2}{|c|}{ T-test\# } \\
\hline & 0.115 & 0.009 & $* * *$ & 0.069 & 0.011 & $* * *$ & 3.24 & $* * *$ & 0.116 & 0.009 & $* * *$ & 0.069 & 0.011 & $* * *$ & 3.31 & $* * *$ \\
\hline Log ( $n$ of employees) & 0.705 & 0.018 & $* * *$ & 0.686 & 0.016 & $* * *$ & -0.79 & & 0.707 & 0.018 & $* * *$ & 0.686 & 0.016 & $* * *$ & -0.87 & \\
\hline Log (materials) & 0.236 & 0.012 & $* * *$ & 0.361 & 0.016 & $* * *$ & 6.25 & $* * *$ & 0.237 & 0.012 & $* * *$ & 0.362 & 0.016 & $* * *$ & 6.25 & $* * *$ \\
\hline Prob innovation & 0.006 & 0.074 & & 0.075 & 0.065 & & 0.70 & & -0.157 & 0.081 & & 0.030 & 0.072 & & 1.73 & $*$ \\
\hline Prob innov and formal IP & 0.162 & 0.083 & $* *$ & 0.111 & 0.070 & & -0.47 & & -0.027 & 0.109 & & 0.131 & 0.083 & & 1.15 & \\
\hline Prob innov and informal IP & -0.067 & 0.057 & & 0.115 & 0.055 & $* *$ & 2.30 & $* *$ & -0.122 & 0.073 & $*$ & 0.047 & 0.065 & & 1.73 & $*$ \\
\hline Prob innov and both & 0.095 & 0.048 & $* *$ & 0.151 & 0.040 & $* * *$ & 0.90 & & 0.008 & 0.067 & & 0.148 & 0.046 & $* * *$ & 1.72 & $*$ \\
\hline F-test for 4 IP variables & \multicolumn{3}{|c|}{$2.8(0.027)^{* *}$} & \multicolumn{3}{|c|}{$0.8(0.554)$} & & & \multicolumn{3}{|c|}{$3.2(0.011)^{* *}$} & \multicolumn{3}{|c|}{$1.6(0.184)$} & & \\
\hline SSR & \multicolumn{3}{|c|}{$1,220.8$} & \multicolumn{3}{|c|}{$1,224.5$} & & & \multicolumn{3}{|c|}{$1,220.0$} & \multicolumn{3}{|c|}{$1,225.3$} & & \\
\hline Standard error & \multicolumn{3}{|c|}{0.613} & \multicolumn{3}{|c|}{0.566} & & & \multicolumn{3}{|c|}{0.613} & \multicolumn{3}{|c|}{0.566} & & \\
\hline Observations (firms) & \multicolumn{3}{|c|}{$3,285(3,022)$} & \multicolumn{3}{|c|}{$3,859(2,831)$} & & & \multicolumn{3}{|c|}{$3,285(3,022)$} & \multicolumn{3}{|c|}{$3,859(2,831)$} & & \\
\hline
\end{tabular}

Standard errors robust to heteroskedasticity, clustered on firm.

$F$ test for difference of product models $=10.5$

$F$ test for difference of process models $=10.4$

SMEs are firms with employment less than 250 .

\# The $t$-test is for the equality of the coefficient between manufacturing and services. 
Table 9: Estimates of the production function by sector

\begin{tabular}{|c|c|c|c|c|c|c|c|c|c|c|c|c|c|c|c|c|}
\hline \multirow{4}{*}{$\begin{array}{l}\text { Dependent variable } \\
\text { Type of innovation } \\
\text { Log (capital) }\end{array}$} & \multicolumn{16}{|c|}{ Log (turnover) } \\
\hline & \multicolumn{8}{|c|}{ Product } & \multicolumn{8}{|c|}{ Process } \\
\hline & \multicolumn{3}{|c|}{ Manufacturing } & \multicolumn{3}{|c|}{ Services \& other } & \multicolumn{2}{|c|}{ T-test\# } & \multicolumn{3}{|c|}{ Manufacturing } & \multicolumn{3}{|c|}{ Services \& other } & \multicolumn{2}{|c|}{$T$-test\# } \\
\hline & 0.027 & 0.010 & $* * *$ & 0.134 & 0.009 & $* * *$ & 7.95 & $* * *$ & 0.028 & 0.010 & $* * *$ & 0.134 & 0.010 & $* * *$ & 7.50 & $* * *$ \\
\hline Log (n of employees) & 0.764 & 0.016 & $* * *$ & 0.587 & 0.014 & $* * *$ & 8.33 & $* * *$ & 0.765 & 0.016 & $* * *$ & 0.587 & 0.014 & $* * *$ & 8.37 & $* * *$ \\
\hline Log (materials) & 0.334 & 0.017 & $* * *$ & 0.266 & 0.012 & $* * *$ & -3.27 & $* * *$ & 0.333 & 0.016 & $* * *$ & 0.266 & 0.012 & $* * *$ & -3.35 & $* * *$ \\
\hline Prob innovation & -0.164 & 0.058 & $* *$ & 0.117 & 0.077 & & 2.91 & $* * *$ & -0.297 & 0.066 & $* * *$ & 0.067 & 0.086 & & 3.36 & $* * *$ \\
\hline Prob innov and formal IP & -0.086 & 0.061 & & 0.254 & 0.096 & $* * *$ & 2.99 & $* * *$ & -0.176 & 0.073 & $* *$ & 0.299 & 0.121 & $* *$ & 3.36 & $* * *$ \\
\hline Prob innov and informal IP & -0.093 & 0.047 & $* *$ & 0.076 & 0.069 & & 2.02 & $* * *$ & -0.171 & 0.056 & $* * *$ & 0.042 & 0.087 & & 2.06 & $* * *$ \\
\hline Prob innov and both & -0.015 & 0.035 & & 0.213 & 0.061 & $* * *$ & 3.24 & $* * *$ & -0.050 & 0.040 & & 0.274 & 0.080 & $* * *$ & 3.62 & $* * *$ \\
\hline F-test for 4 IP variables & \multicolumn{3}{|c|}{$2.1(0.083)^{*}$} & \multicolumn{3}{|c|}{$1.9(0.111)$} & & & \multicolumn{3}{|c|}{$3.9(0.004)^{* * *}$} & \multicolumn{3}{|c|}{$2.8(0.025)^{* *}$} & & \\
\hline SSR & \multicolumn{3}{|c|}{711.7} & \multicolumn{3}{|c|}{1748.2} & & & \multicolumn{3}{|c|}{708.7} & \multicolumn{3}{|c|}{1747.8} & & \\
\hline Standard error & \multicolumn{3}{|c|}{0.482} & \multicolumn{3}{|c|}{0.658} & & & \multicolumn{3}{|c|}{0.481} & \multicolumn{3}{|c|}{0.658} & & \\
\hline Observations (firms) & \multicolumn{3}{|c|}{$3,091(2,430)$} & \multicolumn{3}{|c|}{$4,053(3,272)$} & & & \multicolumn{3}{|c|}{$3,091(2,430)$} & \multicolumn{3}{|c|}{$4,053(3,272)$} & & \\
\hline
\end{tabular}

Standard errors robust to heteroskedasticity, clustered on firm.

$F$ test for difference of product models $=9.2$

$F$ test for difference of process models $=9.4$

Services \& other includes construction, trade, and utilities in addition to services.

\# The $t$-test is for the equality of the coefficient between manufacturing and services. 